\title{
DIMENSIONAL, OSMOTIC, AND CHEMICAL CHANGES OF ERYTH- ROCYTES IN STORED BLOOD. I. BLOOD PRESERVED IN SODIUM CITRATE, NEUTRAL, AND ACID CITRATE- GLUCOSE (ACD) MIXTURES ${ }^{1}$
}

\author{
BY S. RAPOPORT \\ WITH THE TECHNICAL ASSISTANCE OF MARY WING \\ (From the Children's Hosjital Research Foundation and the Department of Pediatrics, Uni- \\ versity of Cincinnati College of Medicine, Cincinnati)
}

(Received for publication August 31, 1946)

\section{INTRODUCTION}

The value of blood, as contrasted with that of plasma or of plasma products, lies chiefly in the ability of its erythrocytes to perform their oxygencarrying function in the circulation of the recipient, the rôle of the other formed elements being considered relatively unimportant. Studies on the storage of whole blood therefore are primarily concerned with the problem of optimal preservation of erythrocytes. Improvements of preservative technique are dependent upon reliable and practical testing procedures of the post-transfusion survival of erythrocytes. While the ability of erythrocytes to survive in the circulation of the recipient, as determined by direct measurement, remains the final criterion of the value of any method of preservation, the laboriousness of the methods available created the need for preliminary testing procedures which could be applied for screening of new preservative solutions before these are submitted to definitive testing in a direct manner. Repeated attempts have been made to use physical, osmotic, and chemical properties of stored blood in vitro as a guide in the appraisal of preservative methods. A short review of the existing information is indicated.

\section{Review of the literature}

The occurrence of hemolysis in stored blood was noted by the earliest observers and has become the most widely used in vitro test of preservation of blood. The retarding effect of glucose on the appearance of hemolysis was reported by Rous and Turner (1) and has been confirmed repeatedly.

\footnotetext{
1 The work described in this paper was done under a contract, recommended by the Committee on Medical Research, between the Office of Scientific Research and Development and the Children's Hospital of Cincinnati.
}

High concentrations of sucrose and dextrin ( 2 to 4 ), and decrease in blood $\mathrm{pH}(2,4$ to 6$)$, have been shown to have similar effects. Some authors have used spontaneous hemolysis as a decisive criterion of the preservation of stored blood ( 7 to 9 ), while others have stressed the variability of this criterion and have emphasized the fallaciousness of conclusions based on its use $(4,5,10)$. Particularly misleading results have been obtained with bloods preserved in electrolyte-poor carbohydrate-rich media, where the observed hemolysis after prolonged storage was incongruently slight when compared with the state of the cells determined by their survival in vivo. Some observers have stressed the "negative" value of the test as means of excluding rather than selecting preservative solutions (4, 11).

Changes in fragility of the erythrocytes also attracted early attention. A progressive increase of osmotic fragility was noted in bloods stored in media isotonic with respect to electrolytes ( 1 to 6 , 9 to 15). The addition of glucose in small amounts slows the progressive increase of fragility during storage ( 1 to 6,9 to $14,16,17$ ). Decrease of blood $\mathrm{pH}$ has a qualitatively similar but less pronounced effect $(2,4$ to 6$)$. In electrolyte-poor media, fragility is often altered peculiarly, depending on the character of the preservative fluid. In De Gowin's or Rous-Turner solutions there is noted early an increased fragility which may revert to normal if the cells are washed free of excess glucose $(4, ?$, 10). In solutions of sucrose, dextrins, or corn syrup, substances which do not permeate the erythrocytic membrane, the cells exhibit an exceedingly low fragility, which does not change in a uniform manner during storage $(1,2,4,7,10)$.

A gradual increase of varying degree in the corpuscular volume of erythrocytes in nearly-iso- 
tonic media has been described by most earlier observers. In electrolyte-poor media variable alterations have been found; while cells in RousTurner's and De Gowin's solution increase progressively to almost hemolytic (bursting) volumes, they swell only transiently and to a minor degree or may even shrink in solutions which contain dextrin, sucrose or other non-permeating carbohydrates $(2,4,11,17)$. Changes in shape and surface of erythrocytes during storage have been described $(18,19)$, the cells becoming more spheroidal in shape, and crenated. The increase in the mechanical fragility of erythrocytes during storage apparently bears no constant relationship to osmotic fragility, spontaneous hemolysis, or survival in vivo $(1,4,7,9)$.

Among the chemical properties of stored blood, changes of $\mathrm{pH}$ have been determined $(4,6,20)$. Unfortunately most measurements have been carried out at a temperature far removed from that in the refrigerator or in the body and are therefore not easily related to actual conditions of use. It has been found that in general the $\mathrm{pH}$ of blood decreases during storage because of glycolysis with lactic acid formation. Liberation of ammonia $(2,21$ to 23$)$ and the exchange of potassium and sodium across the cellular membrane $(2,19$, 20,24 to 27) soon after blood is drawn have been noted by several workers. These changes appear to be somewhat retarded at lower blood $\mathrm{pH}$ values $(19,25)$. The alteration in the distribution of sodium and potassium in the cell seems reversible in vivo following transfusion of the stored blood (28).

Changes in the phosphorus distribution have also attracted the attention of some observers $(2,6,11$, 29,30 ), who found that during storage the organic acid-soluble phosphorus of the erythrocytes decreased in concentration while the inorganic phosphorus rose. Because of the slowness of the outward diffusion great differences between cells and plasma in the concentration of inorganic phosphorus occurred. An association between the changes of the organic acid-soluble phosphorus, in particular the easily-hydrolyzable fraction, and preservability of the cells was indicated by the data $(29,30)$, although the observers emphasized that parallelism between the chemical change and survival in vivo was by no means perfect (11). Among other chemical constituents mention should be made of hemoglobin. Present evidence indicates that over long periods of storage hemoglobin maintains its oxygen-carrying capacity and that the rate of reaction between hemoglobin and oxygen is unimpaired $(12,31)$.

As can be seen from the summary of the information existing at present, the attempts to utilize in vitro changes as a measure of the behavior of the blood cells in the circulation of the recipient have led to results contradictory and disappointing to most observers. While some workers have unqualifiedly used in vitro tests as indices of preservation of blood on the assumption, either voiced or obviously implied, that these measurements reflected the behavior of the erythrocytes in the recipient's circulation $(3,7$ to 9,15$)$, others, in particular those observers who used preservative solutions of high carbohydrate content, came to the conclusion that in vitro testing was worthless as a measure of survival of erythrocytes $(4,10,11)$.

\section{Plan of study}

The study to be reported was undertaken on the basic assumption that the erythrocyte constitutes a functional unit and that therefore its physical and chemical properties are interrelated and dependent on the metabolic activity of the cell. Therefore, one would expect to find a close correspondence between suitably selected and measured physical, osmotic, and chemical indices of the cell, on the one hand, and the ability of erythrocytes to survive in the body of the recipient on the other. It was hoped that comprehensive and integrated information on the behavior of erythrocytes during storage might provide the basis for reliable in vitro testing procedures and for improvements of preservative technique in the light of a deeper insight into the deteriorative processes during storage. With this concept in mind a variety of measurements were carried out simultaneously and seriatim on samples of stored blood, including the dimensions of the erythrocytes, their osmotic behavior, and several chemical constituents. In the chemical studies, emphasis was put on the measurement of glycolysing ability of the cells and of correlated changes in the acid-soluble phosphorus compounds. This emphasis was based on the consideration that glycolysis is the main metabolic activity of red cells and is closely related to their acid-soluble phosphorus compounds. 
In addition, studies of the changes of sodium and potassium were carried out. Recognizing that the behavior of blood cells in electrolyte-poor media may be qualitatively different from that observed in solutions near isotonicity with respect to electrolytes, it was decided to limit the first study to a comparison of the behavior of blood stored in 3 solutions, representative of the main types of nearly-isotonic preservatives in practical use at present.

\section{Composition of preservative solutions}

The solutions studied were: (1) simple citrate solution, (2) a neutral citrate-glucose solution

TABLE I

Composition of preservative solutions

\begin{tabular}{|c|c|c|c|c|c|}
\hline Mixture & $\begin{array}{c}\mathrm{Na} \\
\text { cit- } \\
\text { rate* }\end{array}$ & $\left|\begin{array}{l}\text { Citric } \\
\text { acid* }\end{array}\right|$ & $\begin{array}{l}\text { Glu- } \\
\text { cose* }\end{array}$ & $\mathrm{pH}$ & $\begin{array}{c}\text { Vol- } \\
\text { unte } \\
\text { added } \\
\text { to } \\
100 \\
\text { mi. of } \\
\text { blood }\end{array}$ \\
\hline $\begin{array}{l}\text { 1. Citrate } \\
\text { 2. Citrate-glucose } \dagger \\
\text { 3. Acid citrate-glucose } \dagger \\
\text { (ACD-I) }\end{array}$ & $\begin{array}{c}\text { grams } \\
\text { per } \\
100 \\
\text { ml. } \\
3.20 \\
2.13 \\
1.33\end{array}$ & $\mid \begin{array}{c}\text { grams } \\
\text { per } \\
100 \\
m l . \\
\\
0.47\end{array}$ & $\begin{array}{c}\text { grams } \\
\text { per } \\
100 \\
m l . \\
\\
5.0 \\
3.0\end{array}$ & $\begin{array}{l}(7.5)^{* *} \\
(7.5)^{* *} \\
5.03\end{array}$ & $\begin{array}{l}m l . \\
10 \\
15 \\
25\end{array}$ \\
\hline
\end{tabular}

* Tri-sodium citrate $\cdot 2 \mathrm{H}_{2} \mathrm{O}$, citric acid $\cdot \mathrm{H}_{2} \mathrm{O}$, glucose anhydrous.

** The pH values of these weakly buffered solutions, owing to their dependence on minor extraneous influences, are given in parentheses.

† In preparing the neutral citrate-glucose solution, sterile glucose solution was added aseptically to a sterilized bottle containing the sodium citrate solution, since heating of glucose with neutral citrate results in caramelization to a considerable degree. The acid citrate-glucose mixture (ACD-I), identical with that reported by Loutit (6), was sterilized for 30 minutes at 20 lbs. pressure in a steam autoclave, with minimal signs of discoloration.

containing glucose in a sufficient amount to raise the level in stored blood by 0.6 gram per $100 \mathrm{ml}$., and (3) a citrate-glucose mixture acidified by the addition of citric acid originally used by Loutit and Mollison $(6,32)$. The solutions were added in 15-, 20-, and 25-ml. amounts respectively, to 100 ml. of blood. For the last mixture, in this paper the term ACD-I (an abbreviation of acid citratedextrose), which has gained currency in the United States, will be used interchangeably with acid citrate-glucose. Table I summarizes the essential data concerning the preservative solutions used. As indicated in the table, the first $2 \mathrm{mix}$ tures are approximately neutral, although it must be remembered that the $\mathrm{pH}$ values of such weakly buffered solutions are largely dependent on minor extraneous influences. The $\mathrm{pH}$ value of 5.03 for the acid preservative, which corresponds in composition to a solution of disodium citrate, may be predicted from the molar ratios of sodium citrate and citric acid present in it, on the basis of the known $\mathrm{pK}^{\prime}$ values of the 3 acid groups of citric acid. When this solution is added to blood, only the citric acid significantly affects the $\mathrm{pH}$ of blood, since at the $\mathrm{pH}$ range prevailing in blood, trisodium citrate has an insignificant buffering power.

TABLE II

Citrate, glucose and acid increments in blood after mixture with preservative solutions

\begin{tabular}{|c|c|c|c|c|}
\hline \multirow{2}{*}{ Solution } & \multicolumn{2}{|c|}{ Citrate } & \multirow{2}{*}{$\begin{array}{c}\text { Glucose } \\
\text { increment }\end{array}$} & \multirow{2}{*}{$\begin{array}{c}\text { Acid } \\
\text { increment }\end{array}$} \\
\hline & Blood & Plasma* & & \\
\hline \multirow{4}{*}{$\begin{array}{l}\text { Citrate } \\
\text { Citrate-glucose } \\
\text { Acid citrate- } \\
\text { glucose }\end{array}$} & ${ }_{\text {liter }}^{m}$ per & ${ }_{\text {liter }}^{m M_{\text {per }}}$ & $\begin{array}{l}\text { grams per } \\
100 \mathrm{ml} \text {. }\end{array}$ & $\begin{array}{l}\text { meq. per } \\
\text { liter }\end{array}$ \\
\hline & 10 & 17 & 0 & 0 \\
\hline & 11 & 19 & 0.65 & 0 \\
\hline & 13 & 21 & 0.60 & 16.5 \\
\hline
\end{tabular}

* The values were calculated on the assumption that citrate-ion does not permeate the cell-membrane, with an assumed volume of packed cells in blood of 45 per cent. Water shifts between cells and plasma were neglected.

In Table II are presented the calculated increments of citrate, glucose, and acid resulting in blood from mixing with the preservative solutions. In the first column is listed the citrate concentration in blood; in the next is recorded the more significant value of citrate in the supernatant plasma, calculated on the basis of the well substantiated assumption that the cell membrane is impermeable to citrate ions. The values listed are in excess of those required to suppress the effect of calcium ion on clotting, calculated by Maizels to be $10 \mathrm{meq}$. per liter (33). In the next column are given the calculated increments of glucose in blood. It may be seen that the 2 glucose-containing preservatives are like each other in this respect. In the last column is listed the amount of acid added to blood with the acid preservative solution. This amount would produce a shift in the blood $\mathrm{pH}$ of about 0.5 unit if no bicarbonate were displaceda condition which undoubtedly does not prevail. 
Actually, as described in a later section dealing with $\mathrm{pH}$ change during storage, the $\mathrm{pH}$ of blood was initially shifted by about $0.3 \mathrm{pH}$ unit. The osmotic properties of the preservative solutions and their calculated and observed effects on blood are dealt with in a later section concerning the osmotic behavior of erythrocytes.

\section{HANDLING OF THE BLOOD AND METHODS USED}

For serial sampling, $100-\mathrm{ml}$. amounts of blood were drawn aseptically into bottles containing appropriate amounts of the preservative solution being tested. After mixing, 20-ml. portions of the blood were distributed into vials of $30-\mathrm{ml}$. capacity, similar in shape to the standard blood bank bottles. The blood samples were then placed in a refrigerator maintained at $4^{\circ} \mathrm{C}$. At suitable intervals individual vials were removed for analysis. For the study of the behavior of blood under routine conditions, samples were procured from the blood bank of the Cincinnati General Hospital, where they had been drawn from donors acceptable by the standards of the blood bank, but otherwise unselected, and stored at $4^{\circ} \mathrm{C}$. For testing, the bloods were transported to the laboratory under suitable precautions and sampled within 20 minutes after removal from storage.

The methods used in this laboratory for the determination of the dimensions and of the osmotic behavior of the
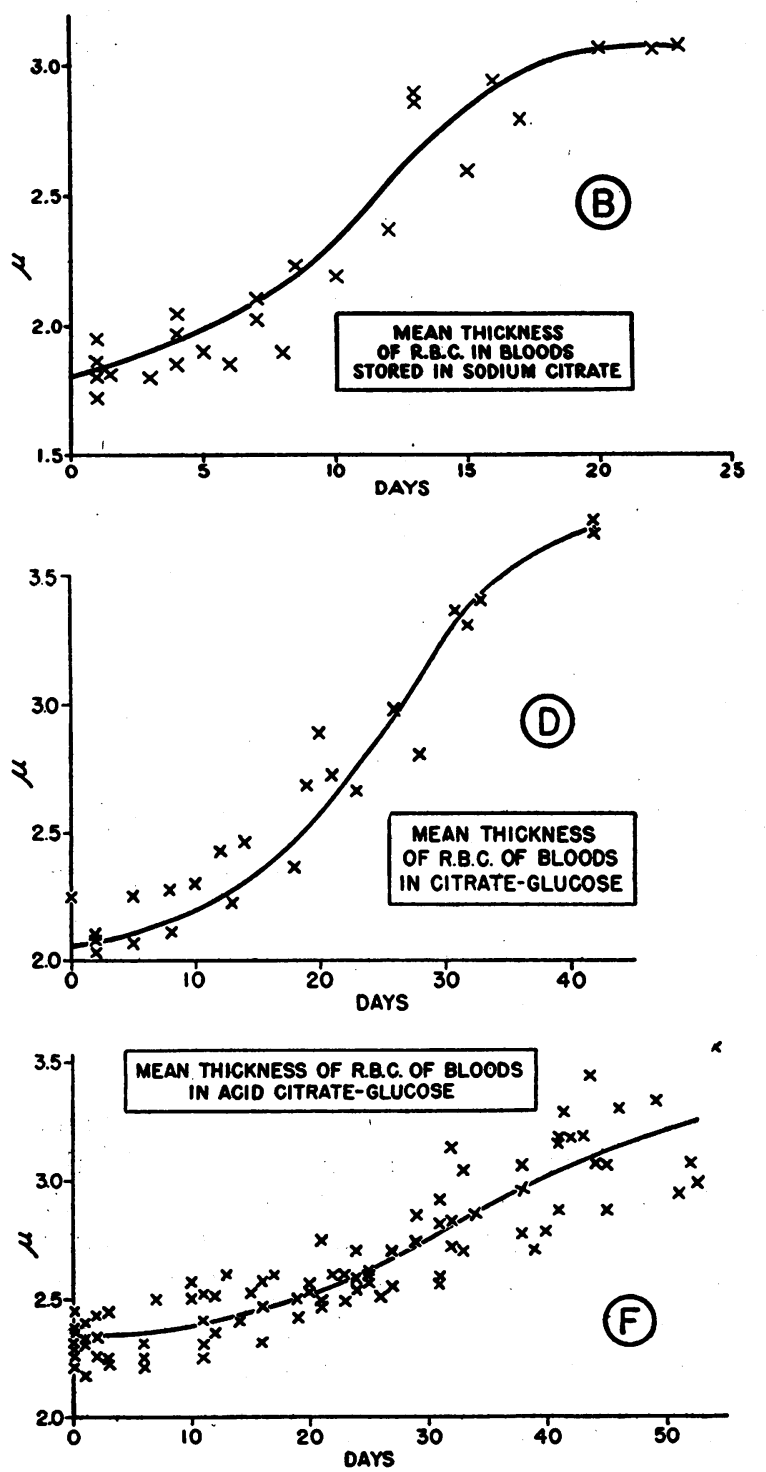

Fig. 1. Dimensional Changes of Erythrocytes of Bloods Stored in Citrate; Citrate-Glucose, and Acid Citrate-Glucose Solutions 
cells have been described previously (34). The chemical methods generally used excepting those for the determination of lactic acid and sugar have also been reported (35). The blood sugar was determined by the method of Nelson (36), and lactic acid by a slightly modified aerationtitration method of Friedemann et al (37). Reference to special methods is made in following sections, where results obtained by their use are discussed.

\section{DIMENSIONAL CHANGES}

Changes of the diameter of the cells and their thickness, calculated from the diameter and volume on the assumption of a disc-shape (34), are presented in Figure 1. (See also columns 1 and 2 of Tables III to V.) It may be seen that in all instances the diameter decreased while the thickness increased. This process is illustrated by the changes in the diameter to thickness ratio which fell from values as high as 4.1 to 2.0 during storage. The mean corpuscular volume of the cells (see column 3 of Tables III to V) rose by about 10 per cent during storage from values close to the normal in both neutral media while it did not change significantly in acid citrate-glucose solution beyond the initial rise to 115 per cent of normal. The mean surface area of the red cells (see column 4 of Tables III to V), also calculated on the assumption of a disc-shape, decreased.

TABLE III

Mean dimensions and maximal volumes of erythrocytes of blood stored in sodium citrate

\begin{tabular}{|c|c|c|c|c|c|c|c|c|}
\hline$\underset{\text { ject }}{\text { Sub- }}$ & $\begin{array}{l}\text { Stor- } \\
\text { age } \\
\text { pe- } \\
\text { riod }\end{array}$ & $\begin{array}{c}\text { Diam- } \\
\text { eter }\end{array}$ & $\begin{array}{l}\text { Thick- } \\
\text { ness }\end{array}$ & $\begin{array}{l}\text { Vol- } \\
\text { ume }\end{array}$ & $\begin{array}{l}\text { Sur- } \\
\text { face } \\
\text { area }\end{array}$ & $\begin{array}{l}\text { Calcu- } \\
\text { lated } \\
\text { volume of } \\
\text { a sphere } \\
\text { with } \\
\text { same } \\
\text { surface } \\
\text { area }\end{array}$ & $\begin{array}{l}\text { Ob- } \\
\text { served } \\
\text { maxi- } \\
\text { mum } \\
\text { vol- } \\
\text { ume of } \\
\text { cells }\end{array}$ & $\begin{array}{c}\text { Tonicity } \\
\text { at which } \\
\text { maxi- } \\
\text { mum } \\
\text { volume } \\
\text { occurred }\end{array}$ \\
\hline & days & $\boldsymbol{\mu}$ & $\mu$ & $\mu^{3}$ & $\mu^{2}$ & $\mu^{2}$ & $\mu^{2}$ & $\begin{array}{c}\text { per cent } \\
\mathrm{NaCl}\end{array}$ \\
\hline J.L. & $\begin{array}{r}1 \\
3 \\
6 \\
8 \\
10 \\
13 \\
16 \\
20 \\
23\end{array}$ & $\begin{array}{l}7.8 \\
7.7 \\
7.7 \\
7.5 \\
7.2 \\
6.4 \\
6.3 \\
6.3 \\
6.3\end{array}$ & $\begin{array}{l}1.82 \\
1.80 \\
1.85 \\
1.90 \\
2.21 \\
2.86 \\
2.95 \\
3.08 \\
3.08\end{array}$ & $\begin{array}{l}87 \\
84 \\
86 \\
84 \\
90 \\
92 \\
92 \\
96 \\
96\end{array}$ & $\begin{array}{l}140 \\
137 \\
138 \\
133 \\
131 \\
122 \\
121 \\
123 \\
123\end{array}$ & $\begin{array}{l}156 \\
151 \\
152 \\
144 \\
141 \\
127 \\
125 \\
128 \\
128\end{array}$ & $\begin{array}{l}159 \\
158 \\
161 \\
150 \\
148 \\
140 \\
120 \\
119 \\
106\end{array}$ & $\begin{array}{l}0.52-0.47 \\
0.52-0.47 \\
0.52-0.47 \\
0.55-0.47 \\
0.60-0.47 \\
0.60-0.47 \\
0.80-0.50 \\
0.85-0.55 \\
0.90-0.65\end{array}$ \\
\hline S.R. & $\begin{array}{r}0^{*} \\
1 \\
4 \\
7 \\
12 \\
17 \\
22\end{array}$ & $\begin{array}{l}7.6 \\
7.6 \\
7.5 \\
7.2 \\
6.9 \\
6.4 \\
6.2\end{array}$ & $\begin{array}{l}1.92 \\
1.86 \\
1.93 \\
2.12 \\
2.37 \\
2.80 \\
3.07\end{array}$ & $\begin{array}{l}87 \\
85 \\
85 \\
86 \\
89 \\
90 \\
93\end{array}$ & $\begin{array}{l}137 \\
135 \\
134 \\
129 \\
126 \\
121 \\
120\end{array}$ & $\begin{array}{l}151 \\
147 \\
146 \\
138 \\
133 \\
125 \\
123\end{array}$ & $\begin{array}{l}159 \\
151 \\
151 \\
129 \\
114 \\
113\end{array}$ & $\begin{array}{l}0.50-0.47 \\
0.55-0.47 \\
0.55-0.50 \\
0.65-0.52 \\
0.80-0.52 \\
0.90-0.52\end{array}$ \\
\hline E.F. & $\begin{array}{c}0 * \\
1 \\
4 \\
11 \\
18\end{array}$ & $\begin{array}{l}7.8 \\
7.7 \\
7.5 \\
6.4 \\
6.1\end{array}$ & $\begin{array}{l}1.97 \\
1.97 \\
2.12 \\
3.07 \\
3.22\end{array}$ & $\begin{array}{r}94 \\
92 \\
94 \\
97 \\
100\end{array}$ & $\begin{array}{l}137 \\
141 \\
138 \\
126 \\
120\end{array}$ & $\begin{array}{l}151 \\
157 \\
152 \\
133 \\
123\end{array}$ & $\begin{array}{l}170 \\
169 \\
127 \\
124\end{array}$ & $\begin{array}{l}0.52-0.45 \\
0.55-0.47 \\
0.70-0.52 \\
0.90-0.70\end{array}$ \\
\hline
\end{tabular}

* Blood sample in heparin.
TABLE IV

Mean dimensions and maximal volumes of erythrocytes of blood stored in citrate-glucose mixture

\begin{tabular}{|c|c|c|c|c|c|c|c|c|}
\hline Sub- & $\begin{array}{l}\text { Stor- } \\
\text { age } \\
\text { pe-- } \\
\text { riod }\end{array}$ & $\begin{array}{c}\text { Diam- } \\
\text { eter }\end{array}$ & $\begin{array}{c}\text { Thick- } \\
\text { ness }\end{array}$ & $\begin{array}{l}\text { Vol- } \\
\text { ume }\end{array}$ & $\begin{array}{l}\text { Sur- } \\
\text { face } \\
\text { area }\end{array}$ & $\begin{array}{l}\text { Calcu- } \\
\text { lated } \\
\text { volume of } \\
\text { a sphere } \\
\text { with } \\
\text { same } \\
\text { surface } \\
\text { area }\end{array}$ & $\begin{array}{c}\text { Ob- } \\
\text { served } \\
\text { maxi- } \\
\text { mum } \\
\text { vol- } \\
\text { ume of } \\
\text { cells }\end{array}$ & $\begin{array}{l}\text { Tonicity } \\
\text { at which } \\
\text { maxi- } \\
\text { mum } \\
\text { volume } \\
\text { occurred }\end{array}$ \\
\hline & days & $\mu$ & $\mu$ & $\mu^{3}$ & $\mu^{2}$ & $\mu^{3}$ & $\mu^{2}$ & $\begin{array}{c}\text { per cent } \\
\mathrm{NaCl}\end{array}$ \\
\hline S.R. & $\begin{array}{c}0^{*} \\
2 \\
5 \\
8 \\
13 \\
18 \\
23 \\
28\end{array}$ & $\begin{array}{l}7.6 \\
7.4 \\
7.4 \\
7.4 \\
7.3 \\
7.1 \\
6.7 \\
6.6\end{array}$ & $\begin{array}{l}1.92 \\
2.03 \\
2.07 \\
2.11 \\
2.22 \\
2.36 \\
2.66 \\
2.80\end{array}$ & $\begin{array}{l}87 \\
88 \\
89 \\
91 \\
93 \\
94 \\
94 \\
96\end{array}$ & $\begin{array}{l}137 \\
133 \\
134 \\
135 \\
135 \\
132 \\
129 \\
126\end{array}$ & $\begin{array}{l}151 \\
144 \\
146 \\
147 \\
147 \\
143 \\
138 \\
133\end{array}$ & $\begin{array}{l}149 \\
150 \\
153 \\
152 \\
141 \\
130 \\
135\end{array}$ & $\begin{array}{l}0.55-0.47 \\
0.55-0.47 \\
0.55-0.50 \\
0.55-0.52 \\
0.60-0.52 \\
0.70-0.52 \\
0.75-0.55\end{array}$ \\
\hline E.F. & $\begin{array}{c}0^{*} \\
2 \\
5 \\
12 \\
19 \\
26 \\
32\end{array}$ & $\begin{array}{l}7.8 \\
7.6 \\
7.4 \\
7.3 \\
6.9 \\
6.5 \\
6.2\end{array}$ & $\begin{array}{l}1.97 \\
2.10 \\
2.26 \\
2.41 \\
2.68 \\
2.98 \\
3.31\end{array}$ & $\begin{array}{r}94 \\
95 \\
97 \\
101 \\
100 \\
99 \\
100\end{array}$ & $\begin{array}{l}144 \\
141 \\
139 \\
139 \\
133 \\
127 \\
125\end{array}$ & $\begin{array}{l}162 \\
157 \\
154 \\
154 \\
144 \\
134 \\
131\end{array}$ & $\begin{array}{l}162 \\
144 \\
144 \\
134 \\
129 \\
124\end{array}$ & $\begin{array}{l}0.55-0.47 \\
0.55-0.50 \\
0.65-0.52 \\
0.70-0.55 \\
0.85-0.60 \\
0.90-0.60\end{array}$ \\
\hline D.B. & $\begin{array}{c}0 * \\
2 \\
8 \\
14 \\
21 \\
33 \\
42\end{array}$ & $\begin{array}{l}7.6 \\
7.4 \\
7.2 \\
7.0 \\
6.7 \\
6.2 \\
5.9\end{array}$ & $\begin{array}{l}2.03 \\
2.09 \\
2.28 \\
2.46 \\
2.72 \\
3.40 \\
3.70\end{array}$ & $\begin{array}{r}92 \\
90 \\
93 \\
95 \\
96 \\
103 \\
101\end{array}$ & $\begin{array}{l}139 \\
135 \\
133 \\
131 \\
128 \\
127 \\
123\end{array}$ & $\begin{array}{l}154 \\
147 \\
144 \\
141 \\
136 \\
134 \\
128\end{array}$ & $\begin{array}{l}149 \\
148 \\
144 \\
133 \\
131 \\
127\end{array}$ & $\begin{array}{l}0.55-0.50 \\
0.55-0.47 \\
0.60-0.52 \\
0.70-0.55 \\
0.75-0.60 \\
0.90-0.65\end{array}$ \\
\hline
\end{tabular}

* Blood sample in heparin.

TABLE V

Mean dimensions and maximal volumes of erythrocytes o, blood stored in acid citrate-glucose mixture I

\begin{tabular}{|c|c|c|c|c|c|c|c|c|}
\hline $\begin{array}{l}\text { Sub- } \\
\text { ject }\end{array}$ & $\begin{array}{l}\text { Stor- } \\
\text { age } \\
\text { pe- } \\
\text { riod }\end{array}$ & $\begin{array}{c}\text { Diam- } \\
\text { eter }\end{array}$ & $\begin{array}{c}\text { Thick- } \\
\text { ness }\end{array}$ & $\begin{array}{l}\text { Vol- } \\
\text { ume }\end{array}$ & $\begin{array}{l}\text { Sur- } \\
\text { face } \\
\text { area }\end{array}$ & $\begin{array}{l}\text { Calcu- } \\
\text { lated } \\
\text { volume of } \\
\text { a sphere } \\
\text { with } \\
\text { same } \\
\text { surface } \\
\text { area }\end{array}$ & $\begin{array}{c}\text { Ob- } \\
\text { served } \\
\text { maxi- } \\
\text { mum } \\
\text { vol- } \\
\text { ume of } \\
\text { cells }\end{array}$ & $\begin{array}{c}\text { Tonicity } \\
\text { at which } \\
\text { maxi- } \\
\text { mum } \\
\text { volume } \\
\text { occurred }\end{array}$ \\
\hline & days & $\mu$ & $\mu$ & $\mu^{2}$ & $\mu^{2}$ & $\mu^{3}$ & $\mu^{2}$ & $\begin{array}{c}\text { per cent } \\
\mathrm{NaCl}\end{array}$ \\
\hline S.R. & $\begin{array}{c}0^{*} \\
0 \\
3 \\
6 \\
11 \\
16 \\
21 \\
26 \\
31 \\
38\end{array}$ & $\begin{array}{l}7.6 \\
7.4 \\
7.4 \\
7.4 \\
7.4 \\
7.3 \\
7.1 \\
7.0 \\
6.9 \\
6.6\end{array}$ & $\begin{array}{l}1.92 \\
2.26 \\
2.24 \\
2.21 \\
2.26 \\
2.32 \\
2.47 \\
2.51 \\
2.59 \\
2.78\end{array}$ & $\begin{array}{l}87 \\
97 \\
97 \\
95 \\
97 \\
97 \\
98 \\
97 \\
97 \\
95\end{array}$ & $\begin{array}{l}137 \\
140 \\
138 \\
137 \\
139 \\
137 \\
134 \\
132 \\
131 \\
126\end{array}$ & $\begin{array}{l}151 \\
156 \\
152 \\
151 \\
154 \\
151 \\
146 \\
143 \\
141 \\
133\end{array}$ & $\begin{array}{l}154 \\
157 \\
158 \\
151 \\
147 \\
145 \\
146 \\
137 \\
139\end{array}$ & $\begin{array}{l}0.52-0.50 \\
0.52-0.50 \\
0.52-0.50 \\
0.55-0.52 \\
0.60-0.52 \\
0.60-0.52 \\
0.60-0.52 \\
0.65-0.55 \\
0.70-0.52\end{array}$ \\
\hline E.F. & $\begin{array}{c}0^{*} \\
0 \\
3 \\
10 \\
17 \\
24 \\
31 \\
38 \\
46\end{array}$ & $\begin{array}{l}7.8 \\
7.6 \\
7.5 \\
7.3 \\
7.2 \\
7.1 \\
6.9 \\
6.7 \\
6.4\end{array}$ & $\begin{array}{l}1.97 \\
2.36 \\
2.44 \\
2.57 \\
2.60 \\
2.70 \\
2.82 \\
3.06 \\
3.29\end{array}$ & $\begin{array}{r}94 \\
107 \\
108 \\
108 \\
106 \\
107 \\
105 \\
108 \\
106\end{array}$ & $\begin{array}{l}144 \\
147 \\
145 \\
143 \\
140 \\
139 \\
136 \\
135 \\
130\end{array}$ & $\begin{array}{l}162 \\
167 \\
164 \\
161 \\
156 \\
154 \\
149 \\
147 \\
139\end{array}$ & $\begin{array}{l}164 \\
163 \\
162 \\
141 \\
144 \\
138 \\
134 \\
125\end{array}$ & $\begin{array}{l}0.55-0.50 \\
0.55-0.52 \\
0.55 \\
0.65-0.52 \\
0.70-0.52 \\
0.75-0.52 \\
0.75-0.55 \\
0.90-0.65\end{array}$ \\
\hline D.B. & $\begin{array}{c}0 * \\
1 \\
7 \\
13 \\
20 \\
32 \\
41\end{array}$ & $\begin{array}{l}7.6 \\
7.3 \\
7.1 \\
7.1 \\
7.0 \\
6.7 \\
6.7\end{array}$ & $\begin{array}{l}2.03 \\
2.39 \\
2.49 \\
2.56 \\
2.60 \\
2.83 \\
2.87\end{array}$ & $\begin{array}{r}92 \\
100 \\
98 \\
101 \\
100 \\
100 \\
101\end{array}$ & $\begin{array}{l}139 \\
139 \\
135 \\
136 \\
134 \\
131 \\
131\end{array}$ & $\begin{array}{l}154 \\
154 \\
147 \\
149 \\
146 \\
141 \\
141\end{array}$ & $\begin{array}{l}150 \\
149 \\
145 \\
144 \\
135 \\
137\end{array}$ & $\begin{array}{l}0.55-0.52 \\
0.55-0.52 \\
0.55-0.52 \\
0.60-0.52 \\
0.70-0.55 \\
0.75-0.52\end{array}$ \\
\hline
\end{tabular}

* Blood sample in heparin. 
A comparison of the 3 preservatives with regard to the dimensions of the erythrocytes indicates that at the outset the cells of citrated blood were slightly shrunken and flatter, those of blood in acid citrate-glucose somewhat swollen and rounder, and those in citrate-glucose of about the same shape and size as were the cells of heparinized-samples. During storage the values for diameter and thickness increasingly approached each other with resulting increased "roundness" of the cells. The pattern of change, with its characteristic sigmoid-shaped time curve, was essentially the same in all preservatives as was the final form attained by the cells. The behavior of the red cells in the 3 preservatives differed primarily in the length of time required for the dimensional alterations to run their course. For instance, while the cells in citrate required 10 days on the average to reach a diameter of less than 6.6 and a thickness of more than 2.8 micra, cells in citrate-glucose assumed a comparable shape in about 25 days and those in acid citrate-glucose, in about 35 days. The differences in the rates of dimensional change are illustrated more clearly in Figure 2, in which

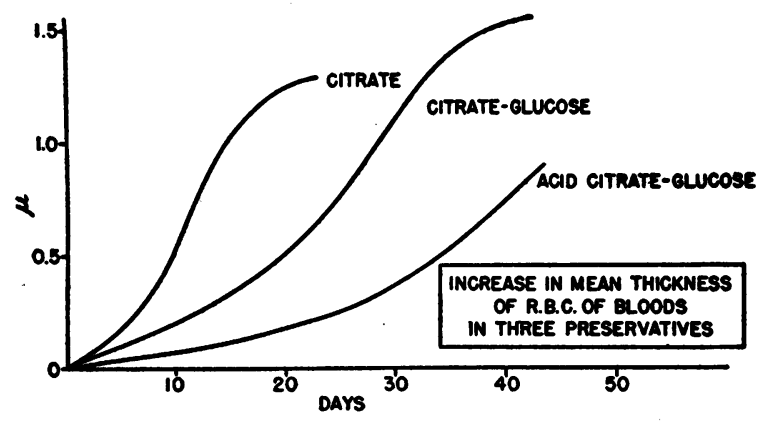

Fig. 2. Average Increase in Mean Thickness of Erythrocytes Stored in 3 Preservative Solutions

the 3 preservatives are compared with respect to the average increase in thickness of the erythrocytes above the initial value. A similar order is oberved in the changes in the calculated surface area.

The calculated decrease in the mean surface area of the cells during storage may be explained as follows: if the assumption is accepted that the mean surface area of a given cell population is constant, as suggested by several observers, the calculated decrease of the area might be apparent only; the hypothesis may be then advanced that an interrelation exists between the calculated change in surface area and the microscopically visible crenation; going one step further, one may assume that the extent of the calculated alteration in the surface area is a reflection, perhaps even a quantitative measure, of the degree of crenation of the erythrocytes.

The alterations in the dimensions of the red cell during storage may be interpreted as manifestations of increasing deterioration of the cell form, resulting in increasing roundness of the cell, or more exactly, in closer approximation of all cell diameters. In this process the cell is changed in form from a biconcave disc to the shape of a wrinkled bag. The "S"-shaped pattern of change with time in the dimensions of the cell, characteristic of phenomena of biological growth and decay, would indicate a relationship between the dimensional and functional state of the cell.

The alterations in the corpuscular volume of the cells, initially and during storage, will be discussed in detail in the following section. They appear to be determined primarily by changes in the osmotic relationships and by shifts of the $\mathrm{pH}$ in cells and plasma. Here, it may be pointed out that the disproportion between the increasing approximation of all cell diameters and the change of the cellular volume, seems at least partly to account for the crenation of stored erythrocytes.

\section{OSMOTIC CHANGES}

In Figures 3, 4 and 5 are presented data on the percentage of erythrocytes hemolyzed in varying concentrations of sodium chloride. The data for hemolysis in 0.9 per cent sodium chloride solution, while not a direct measure of true "spontaneous" hemolysis, i.e., of the amount of hemoglobin released in the supernatant plasma, are comparable to the amounts measured in the plasma after mixing and centrifugation of stored blood. The hemolysis curves are presented as plots of percentage of cells hemolyzed in different concentrations of sodium chloride at any given time and as time curves for any given concentration of sodium chloride. Also included in the presentation are combined data on several bloods in 0.6 per cent sodium chloride solution, chosen as representative of the osmotic behavior of the erythrocytes.

In comparing the 3 preservatives with respect 

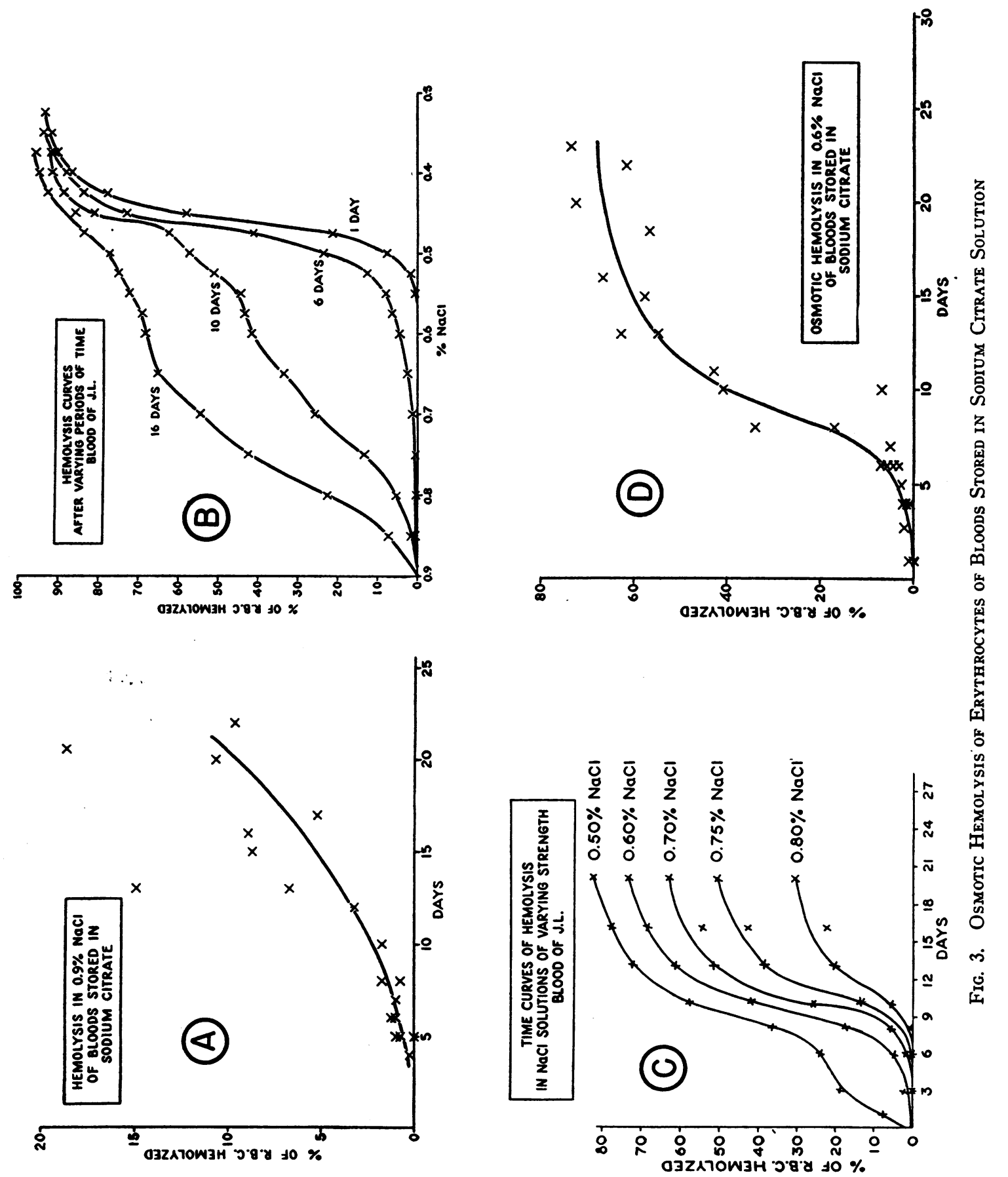
S. RAPOPORT
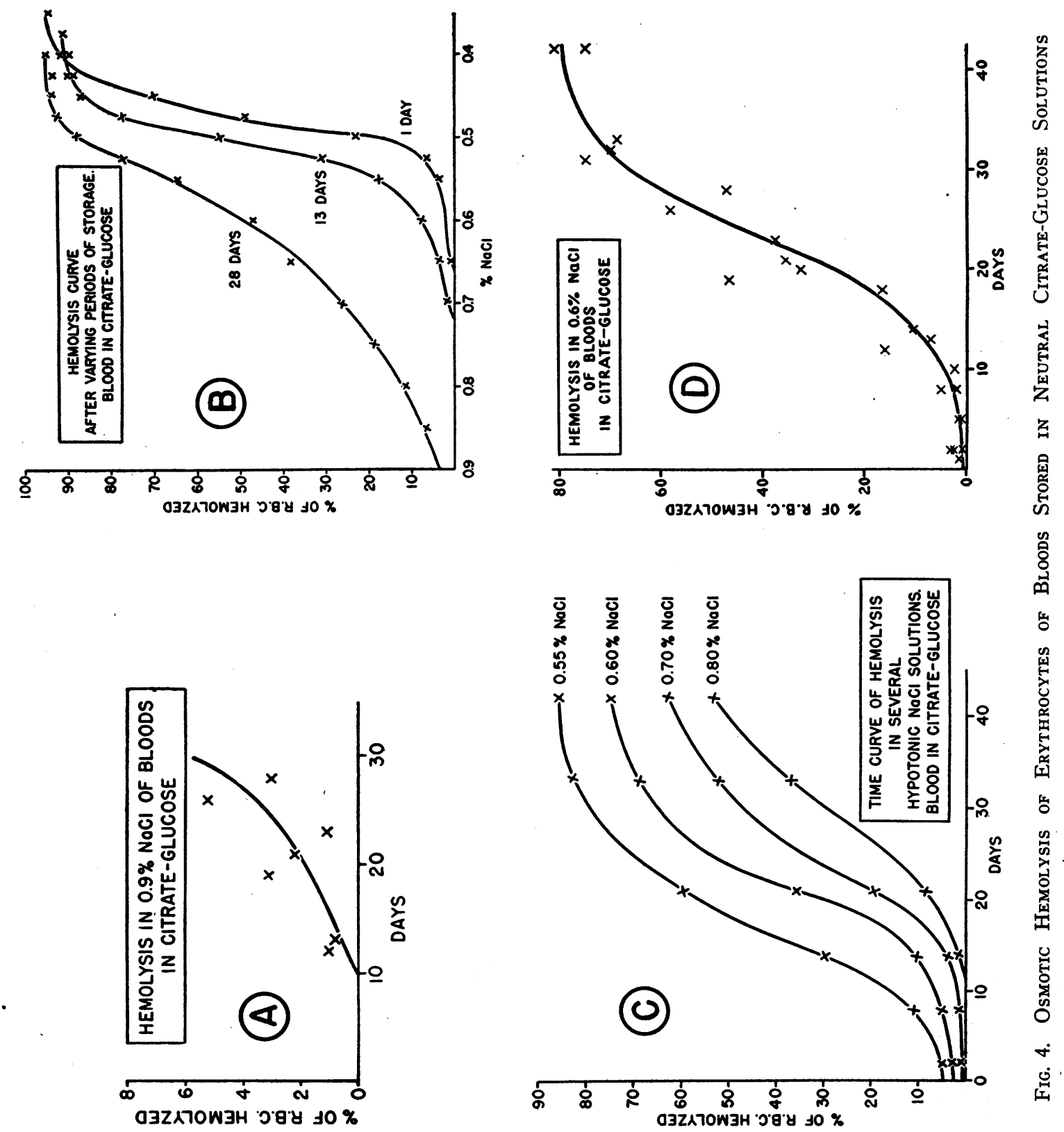

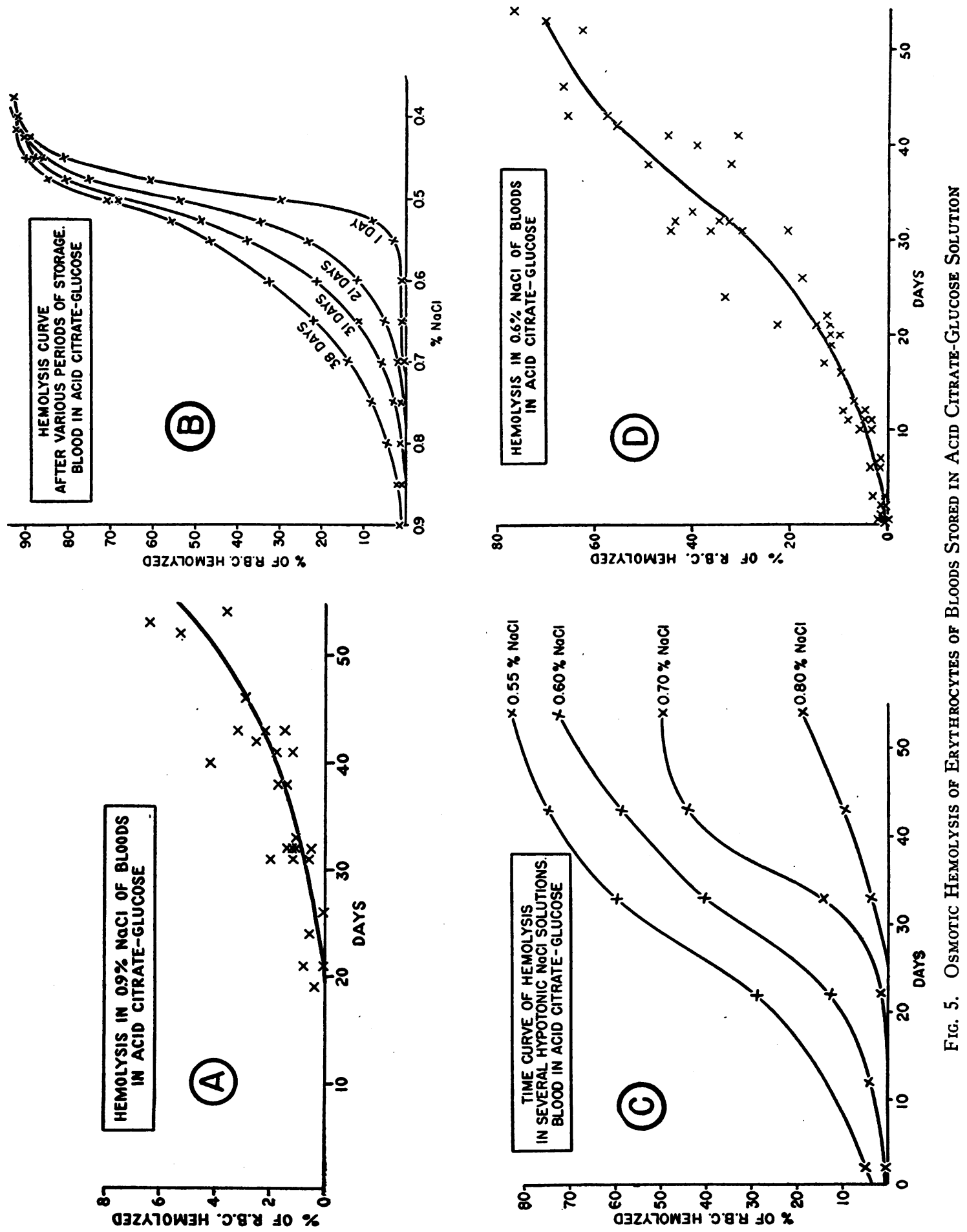
to hemolysis in 0.9 per cent $\mathrm{NaCl}$ solution, it is evident that significant degrees of hemolysis were observed earliest and that hemolysis increased at the most rapid rate in simple citrate solution, while it was latest and slowest to increase in acid citrateglucose.

From an inspection of the hemolysis curves it is apparent that, from being closely similar for all 3 preservatives at the outset, they changed during prolonged storage at different rates. The earliest and most rapid change occurred in the citrate and the slowest, in the acid citrate-glucose solution. An examination of the time curves of hemolysis in different hypotonic salt solutions, which lend themselves better for comparison, indicates that the 3 preservatives arrange themselves in the same order with respect to osmotic hemolysis as they did with regard to dimensional changes and hemolysis in 0.9 per cent $\mathrm{NaCl}$ solution.

It should be pointed out that the usual qualitative way of measuring fragility-noting only the points of beginning and of completed hemolysiswould have resulted in a highly misleading picture of the changes occurring, owing to the fact that a small proportion of the cells showed greatly increased fragility after a few days of storage, thus shifting the point of beginning hemolysis to a considerable extent, while the bulk of the erythrocytes was affected at a much later date. This consideration is of particular importance in the study of bloods collected in glucose-containing preservative solutions, where a minute fraction, less than 1.0 per cent, of the cells exhibited greatly increased fragility immediately following the collection of the blood, causing a shift in the point of beginning hemolysis to $\mathrm{NaCl}$ concentrations of 0.7 per cent or higher.

The data on hemolysis on 0.9 per cent $\mathrm{NaCl}$ solution presented here are comparable to those reported by others on "spontaneous" hemolysis $(5,7)$. With respect to hemolysis in hypotonic salt solutions, a pattern of change similar to that described here was observed by those workers who followed the percentage hemolysis of erythrocytes in a given salt solution during storage $(5,17,30)$. However, different results were reported by those authors who used median corpuscular fragility (38), that is, the tonicity of a salt solution in which 50 per cent of erythrocytes are lysed, as a measure of the osmotic behavior of erythrocytes. This in- dex is unsatisfactory because of the fact that great differences in the percentage of erythrocytes hemolyzed result from small variations in salt concentration. The median corpuscular fragility is susceptible to the influence of changes in temperature and $\mathrm{pH}$ and is affected by a number of minor variations of experimental technique (39). Workers who used this test observed marked alteration initially in bloods stored in various glucose-containing preservatives but noted also that this index changes more gradually with time in bloods preserved in acid than in neutral mixtures (4).

From a consideration of the data here presented one may exclude the hypothesis that hemolysis in 0.9 per cent $\mathrm{NaCl}$ solution, or so-called "spontaneous" hemolysis, can be due to osmotic factors. During storage the cells swell only by 10 per cent, far below their critical volume; and there is no relation apparent between the extent of the increase in volume and the degree of hemolysis. Other circumstances, such as lytic factors in the plasma, may account for the hemolysis of stored erythrocytes in nearly-isotonic media. The fact that spontaneous hemolysis increased with the period of storage may be explained on the assumption that the presumed lytic factors affected deteriorated cells only. If such were the case, the degree of spontaneous hemolysis would represent a measure of the degenerative processes taking place in the cells, affecting perhaps primarily the cell membrane.

Critical volume of hemolysis: Additional information concerning the process of osmotic hemolysis can be gathered from a comparison of expected and observed maximal (critical) volumes of the cells. The calculation of this cell characteristic is based on 2 assumptions: (1) that the cell membrane cannot be stretched, so that the mean surface area is constant for a given cell population, and (2) that the cells are capable of reaching the shape of a perfect sphere. Granted these assumptions, a cell could reach a maximal volume equal to that of a sphere possessing the same mean surface area. This point, the critical volume, would coincide with the beginning of hemolysis. Available data generally are in good agreement with this theory.

In column 5 of Tables III to $\mathrm{V}$ are tabulated for citrated blood the maximal volumes after various periods of storage, calculated on the basis of the 
corresponding values for the surface area. It can be seen that during storage both observed and calculated maximal volumes, while agreeing reasonably well with each other, decreased from the initial values.

The tonicity of the salt solution at which maximum swelling occurred is tabulated in column 7 of Tables III to V. With increasing time of storage, maximal swelling took place at increasingly high concentrations of $\mathrm{NaCl}$ solution. The zone of maximal swelling which may be defined within narrow limits in fresh blood, became less clearly delimited and broader. On examining the data on the osmometric behavior as well as on the maximal volumes of the cells after extended periods of storage it should be remembered that they are not representative of the state of the cell population as a whole since they are descriptive only of cells remaining unhemolyzed, which by then may constitute half or less of the total cell population. In a comparison with respect to change in maximal volume of the erythrocytes, the 3 preservatives range themselves in the same order and at closely similar intervals, as they did in the preceding comparisons.

Two interpretations of the changes in the maximal volume during storage and of the coincidence of the calculated and observed figures may be offered: (1), that the surface area actually decreased during storage, with corresponding actual change in the maximal volume attainable by the cells and (2), that the apparent decrease of the surface area parallels in extent only the degree of crenation of the erythrocytes; in that case, the expected maximal volume should have remained the same throughout the storage period. The coincidence of the observed maximal volumes with the expected ones calculated on the basis of the apparent decrease of the surface area might be explained as a reflection of the loss of elasticity of the cell membrane, perhaps of its inability to unfold completely to an uncrenated form.

A comparison of hemolysis and volume change of the erythrocytes in hypotonic salt solutions with their maximal critical volumes suggests that during storage the erythrocytes became hemolyzed at volumes increasingly far below their calculated critical volumes. This behavior may signify that the cells, possibly owing to progressive deteriora- tion of the elastic properties of the cell membrane, hemolyze before attaining the spherical shape.

In general, the osmotic properties of the erythrocytes suggest the conclusion that the functional state of the cell, perhaps more specifically that of the cell membrane, during storage becomes the limiting factor determining its behavior rather than the osmotic relationships between the cell and its surrounding medium.

Corpuscular volume: In the following, changes in the corpuscular volume of erythrocytes during storage will be considered from the standpoint of the osmotic relationships obtaining in blood. The discussion will deal with this problem under 2 headings: (1) the initial changes, calculated and observed, produced by the addition of preservatives and (2) the changes occurring during storage. In considering the first point, it may be useful to list the osmotic properties of the preservative solutions employed and their calculated effect on the electrolyte and osmotic concentration of blood. As may be seen from Table VI, the solutions var-

TABLE VI

Osmolarity of preservative solutions and resulting changes in the osmotic and electrolyte concentration of blood

\begin{tabular}{|c|c|c|c|}
\hline Solution & $\begin{array}{l}\text { Cit- } \\
\text { rate }\end{array}$ & $\begin{array}{l}\text { Cit- } \\
\text { rate- } \\
\text { glu- } \\
\text { cose }\end{array}$ & $\begin{array}{l}\text { Acid } \\
\text { cit- } \\
\text { rate- } \\
\text { glu- } \\
\text { cose }\end{array}$ \\
\hline $\begin{array}{l}\text { Sodium citrate, mM. per liter } \\
\text { Sodium citrate, m. osm. per liter } \\
\text { Citric acid, } m \text {. osm. per liter } \\
\text { Glucose, } m \text {. osm. per liter }\end{array}$ & $\begin{array}{l}109 \\
436\end{array}$ & $\begin{array}{r}73 \\
292 \\
278\end{array}$ & $\begin{array}{r}45 \\
181 \\
22 \\
167\end{array}$ \\
\hline $\begin{array}{l}\text { Total osmolarity of solution, m. osm. per liter } \\
\text { Total osmolarity of solution, per cent of initial } \\
\text { blood tonicity } \\
\text { Effective tonicity,* m. osm. per liter } \\
\text { Effective tonicity, per cent of blood tonicity }\end{array}$ & $\begin{array}{l}436 \\
141 \\
436 \\
141 \\
\end{array}$ & $\begin{array}{r}570 \\
184 \\
292 \\
94\end{array}$ & $\begin{array}{r}370 \\
119 \\
203 \\
66\end{array}$ \\
\hline $\begin{array}{l}\text { Osmolarity of blood after mixing, } t \text { m. osm. per } \\
\text { liter } \\
\text { Osmolarity of blood after mixing, per cent of } \\
\text { initial } \\
\text { Electrolyte concentration of blood after mixing, } \\
\text { per cent of initial }\end{array}$ & $\begin{array}{l}324 \\
104 \\
104\end{array}$ & $\begin{array}{r}351 \\
113 \\
99\end{array}$ & $\begin{array}{r}324 \\
104 \\
92\end{array}$ \\
\hline
\end{tabular}

* As effective tonicity is designated, this is the osmotic concentration of substances which permeate the cellmembrane very slowly, if at all. In this instance its value was calculated on the assumption that the electrolytes, but not glucose, conform to this condition.

$t$ Calculated on the basis of an initial concentration of 310 milliosmols per liter of water in blood, and of a water content of $\mathbf{0 . 8 0}$ gram per gram of blood.

ied considerably among themselves with respect to their composition: simple citrate preservative is a hypertonic solution with respect to total solutes as well as electrolytes, while citrate-glucose, although osmotically more concentrated, is actually 
almost isotonic with blood in terms of effective tonicity, owing to the permeability of the cellular membrane to glucose. Acid citrate-glucose solution, which also contains a higher concentration of solutes than blood, is hypotonic with respect to its electrolyte content. The changes in the osmotic and electrolyte concentration of blood, listed in the same table, were calculated on the basis of an assumed initial water content of 0.80 gram per gram of blood, and an osmolarity of 310 milliosmols per liter of water in blood. In the first 2 columns of Table VII are listed observations on the corpuscu-

TABLE VII

\section{Change in corpuscular volume during storage}

The results represent the mean value, together with the standard error of the mean.

\begin{tabular}{|c|c|c|c|c|}
\hline \multirow[b]{2}{*}{ Solution } & \multirow[b]{2}{*}{$\begin{array}{l}\text { Storage } \\
\text { period }\end{array}$} & \multicolumn{2}{|c|}{ Cells in own plasma } & \multirow{2}{*}{$\begin{array}{c}\text { Volume } \\
\text { of } \\
\text { packed } \\
\text { cells } \\
\text { in } 0.9 \\
\text { per cent } \\
\mathrm{NaCl}\end{array}$} \\
\hline & & $\begin{array}{l}\text { Corpus- } \\
\text { cular } \\
\text { volume }\end{array}$ & $\begin{array}{l}\text { Corpus- } \\
\text { cular } \\
\text { hemo- } \\
\text { globin } \\
\text { concen- } \\
\text { tration }\end{array}$ & \\
\hline Citrate & $\begin{array}{l}\text { days } \\
\quad 0 \\
20-30 \\
\text { Per cent change } \\
\text { from initial } \\
\text { value }\end{array}$ & $\begin{array}{c}\text { per cent } \\
\text { of } \\
\text { "normal"* } \\
97.6 \pm 0.6 \\
104.3 \pm 0.9 \\
\\
+6.9 \pm 0.9\end{array}$ & $\begin{array}{c}\text { per cent } \\
\text { of } \\
\text { "normal"** } \\
104.0 \pm 0.4 \\
95.9 \pm 0.9 \\
\\
-7.8 \pm 0.9\end{array}$ & 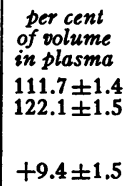 \\
\hline $\begin{array}{l}\text { Citrate- } \\
\text { glucose }\end{array}$ & $\begin{array}{l}\quad 0 \\
\quad 20-30 \\
\text { Per cent change } \\
\text { from initial } \\
\text { value }\end{array}$ & $\begin{array}{r}99.3 \pm 1.2 \\
106.0 \pm 1.0 \\
\\
+6.7 \pm 1.0\end{array}$ & $\begin{array}{r}101.2 \pm 0.5 \\
93.6 \pm 0.6 \\
-7.5 \pm 0.6\end{array}$ & $\begin{array}{l}111.0 \pm 1.2 \\
117.4 \pm 1.0 \\
+5.8 \pm 1.0\end{array}$ \\
\hline $\begin{array}{l}\text { Acid citrate- } \\
\text { glucose }\end{array}$ & $\begin{array}{l}\quad 20 \\
\quad 20-40 \\
\text { Per cent change } \\
\text { from initial } \\
\text { value }\end{array}$ & $\begin{array}{r}113.0 \pm 0.3 \\
113.0 \pm 0.3 \\
0.0 \pm 0.3\end{array}$ & $\begin{array}{r}89.3 \pm 0.7 \\
89.3 \pm 0.7 \\
0.0 \pm 0.3\end{array}$ & $\begin{array}{r}100.0 \pm 0.4 \\
108.5 \pm 0.4 \\
+8.5 \pm 0.4\end{array}$ \\
\hline
\end{tabular}

* The values in heparinized blood samples have been designated as "normal."

lar volume and on the cellular concentration of hemoglobin, expressed as percentage of simultaneously determined values on heparinized blood samples. It may be seen that the initial values for the corpuscular volume and the hemoglobin concentration of erythrocytes in both neutral preservatives agreed reasonably well with the predicted values, while the cells in the acid preservative were considerably more swollen. This difference is largely accounted for in terms of the Donnan theory by the additional effect of lowering of $\mathrm{pH}$ on the corpuscular volume of the cells. By the use of equations descriptive of the distribution of water between cells and plasma (40), acidification per se may be calculated to produce an increase in the corpuscular volume of erythrocytes of about 6 per cent. ${ }^{2}$ While many of the values adopted for the calculation are approximations and while several factors have been neglected, it may be justifiably assumed that the variable of major importance is the ionic equivalency of hemoglobin which is determined by the value of cell $\mathrm{pH}$. The cumulative effects of the changes in osmolarity and $\mathrm{pH}$ of blood in acid citrate-glucose solution would result in an increase of the corpuscular volume of erythrocytes of about 14 per cent, a value in good agreement with the observed one.

2 The theoretical changes in the water content of the plasma may be calculated by means of equations 23 and 24 of Van Slyke, Wu and McLean (40).

$$
\begin{aligned}
& \left(\mathrm{H}_{2} \mathrm{O}\right)_{s}=\left(\mathrm{H}_{2} \mathrm{O}\right)_{b} \times \frac{2(B)_{s}-(B P)_{s}}{2(B)_{b}-(B P)_{s}-(B P)_{c}+(H b)} \\
& \left(\mathrm{H}_{2} \mathrm{O}\right)_{c}=\left(\mathrm{H}_{2} \mathrm{O}\right)_{b} \times \frac{2(B)_{c}-(B P)_{c}+(H b)}{2(B)_{b}-(B P)_{s}-(B P)_{c}+(H b)}
\end{aligned}
$$

in which the parentheses denote units of substance per unit of whole blood, and the subscripts, s, $c, b$ refer to plasma, cells, and whole blood, respectively. $B, P$, and $\mathrm{Hb}$ refer to the sum of cations, the non-diffusible anions, and the osmolarity of hemoglobin, respectively. The following assumptions and substitutions were used in applying this equation: It was assumed that all factors except for $(B P)_{0}$, by which the equivalency of the non-diffusible anions in the red cells is designated, did not change on acidification. A numerical value of $0.84 \mathrm{gram}$ per $\mathrm{ml}$. was assigned to $\left(\mathrm{H}_{2} \mathrm{O}\right)_{0}$, the water content of whole blood. An initial cell volume of 36 per cent was assumed. To $(B)_{b}$, the total cations of whole blood, a value of 138 meq. per liter was assigned, and to $(B)$, the cations of serum, a value of 93 meq. per liter. To $(B P)_{\text {s, the ionic }}$ equivalency of the serum proteins, a value of 10 was given, on the basis of an assumed protein concentration of 7 grams per $100 \mathrm{ml}$. of plasma. For the hemoglobin portion of $(B P)_{0}$, an initial value of 16 was calculated on the basis of an assumed hemoglobin concentration of $5 \mathrm{mM}$. per liter, a cell $\mathrm{pH}$ of 7.20 , and an iso-ionic point of reduced hemoglobin of 6.81 at $38^{\circ} \mathrm{C}$. For the buffering power the value of Adair (41), 9.2 meq. per mol. of hemoglobin was adopted. The ionic equivalency of hemoglobin after acidification of the blood to $\mathrm{pH}$ values between 6.9 and 7.0 in the plasma was taken as zero, on the assumption of a cell $\mathrm{pH}$ at the iso-ionic point of hemoglobin. Constant values of 14 and 9, respectively, were given to the ionic equivalency of the organic phosphates and the osmolarity of the non-diffusible anions in the cells. Given these assumptions, a value of 0.603 gram of plasma water initially and of 0.566 after acidification was calculated. This transfer of water from the plasma to the cells would result in an increase of 6.0 per cent of the corpuscular volume of the cells. 
During storage the corpuscular volume increased and the corpuscular hemoglobin concentration correspondingly decreased in bloods stored in the neutral solutions while these indices remained unchanged in bloods collected in the acid medium in which the cells from the outset had assumed an increased volume. It would appear that, in part, the change of the corpuscular volume in the neutral media during storage was due to the lowering of $\mathrm{pH}$ with a consequent shift in the distribution of water between cells and plasma, as predicted by the Donnan theory. However, it is evident that other factors are also involved, since the $\mathrm{pH}$ in the initially acidified blood continued to decrease without any further change in the corpuscular volume. This behavior will be discussed more fully in a later section dealing with the changes of cations.

Owing to the fact that during storage cations as well as anions permeate the cell membrane, the corpuscular volume of erythrocytes in their own plasma cannot be taken as an indication of alterations occurring in the total osmotic concentration of blood. In this connection it is of interest to compare the volume assumed by erythrocytes of stored blood suspended in 0.9 per cent sodium chloride solution with that observed in their own plasma. From such a comparison a rough indication of the osmotic content of erythrocytes may be expected on condition that in the brief periods of test the cations diffuse only slowly. In column 3 of Table VII are recorded data on the corpuscular volume of erythrocytes of stored blood suspended in 0.9 per cent sodium chloride, expressed as percentage of the simultaneously determined volume in their own plasma. It is apparent that even initially the volume of the erythrocytes in the neutral preservatives, but not in the acid one, exceeded the value measured in their own plasma. After prolonged periods of storage the difference between the 2 measurements increased in all 3 preservatives. The variable initial behavior of erythrocytes in 0.9 per cent sodium chloride does not appear explicable by known osmotic factors.

The explanation nearest at hand for the uniformly increased difference between the volume of erythrocytes in their own plasma and that in 0.9 per cent sodium chloride solution during storage appears to be that, with time, blood becomes increasingly hypertonic with respect to 0.9 per cent sodium chloride solution. owing to the breakdown of larger molecules into smaller ones. Three processes occurring during storage which may influence the osmolarity of blood may be cited: (1) the accumulation of lactic acid, (2) the breakdown of organic phosphates and (3) decomposition of glutathione. These processes, detailed consideration of which would occupy too much space, may roughly be estimated to result in an increase of the osmolarity of blood by 5 per cent. This estimate falls below the actually observed change in the corpuscular volume in 0.9 per cent sodium chloride solution during storage, particularly so, when it is considered that some outward diffusion of solutes must take place during the brief exposures to 0.9 per cent sodium chloride solution.

\section{Plasma $p H$}

The determination of $\mathrm{pH}$ was carried out at $37.5^{\circ} \mathrm{C}$. ; the values recorded in Figure 6 are there-

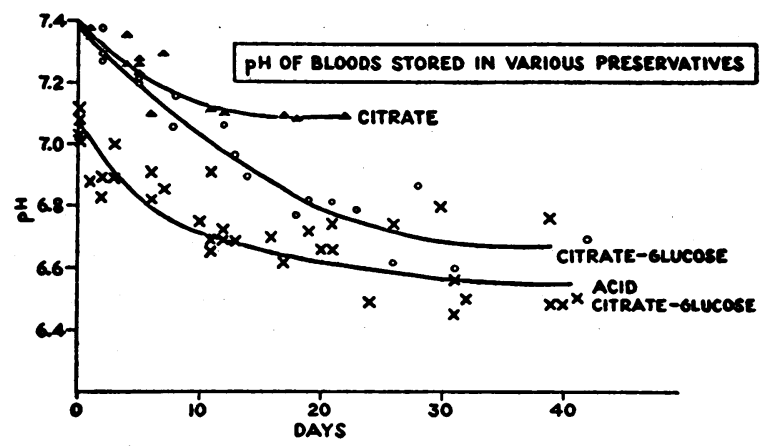

Fig. 6. pH Changes During Storage of Bloods Stored in 3 Preservative Solutions

fore directly comparable to those customarily measured in biological studies. Under the experimental conditions, where loss of $\mathrm{CO}_{2}$ owing to exposure to air could not be avoided, the results are of relative value only. The pattern and extent of the changes in $\mathrm{pH}$ were obviously related to the rate and amount of lactic acid production during storage, the cessation of the downward shift of $\mathrm{pH}$ in citrated blood coinciding with the disappearance of glucose, while in the glucose-enriched media exhaustion of the glycolytic power of the erythrocytes was the limiting factor.

In general, the $\mathrm{pH}$ change during storage in a given blood is dependent on the amount of lactic acid accumulating, on the one hand, and on the type and quantity of buffers present, on the other. 
As lactic acid accumulates, $\mathrm{CO}_{2}$ is lost from the blood in increasing measure, reaching levels as low as 6 meq. per liter after 10 days of storage in glucose-containing media. Among the buffers, hemoglobin is the most important, with phosphates and serum protein following in order. The effect of citrate ion on the ionic balance deserves some comment. The effect of trisodium-citrate on the buffering of the blood may be neglected under the initial conditions of storage, in view of the fact that the $\mathrm{pK}^{\prime}$ even of the third acid group of citric acid at 5.7 is too far removed from the normal $\mathrm{pH}$ of the blood to be of importance. The presence of citric acid in acid citrate-glucose mixture serves more to poise the blood at low $\mathrm{pH}$ values from the beginning than to change its buffering qualities, while the addition of tri-sodium citrate in this solution has a negligible effect on either $\mathrm{pH}$ or buffering. The great retardation in the rate of fall of $\mathrm{pH}$ during storage can be ascribed to 2 factors : (1) a decreased rate of glycolysis and with it of lactic acid accumulation and (2) the fact that the buffering power of the blood increases as it becomes more acid and is near a maximum at about $\mathrm{pH}$ 6.6. Phosphates, present in a concentration of $15 \mathrm{mM}$. per liter of erythrocytes at this $\mathrm{pH}$, exert their maximum buffering effect, and hemoglobin, close to its iso-ionic point, begins to function as a cation. With lowering of $\mathrm{pH}$ the citrate buffering also increases in importance.

\section{Blood sugar, lactic acid, and glycolysis}

The sugar concentration of citrated blood, shown in Figure 7A, diminished swiftly, reaching levels of about $10 \mathrm{mgm}$. per $100 \mathrm{ml}$. on the eighth day of storage, such levels presumably representing residual nonfermentable reducing substances. The curve of the lactic acid accumulation, portrayed in the same figure, complements that of glucose disappearance. Together the 2 curves demonstrate within the limits of the methods used that glucose was entirely converted into lactic acid, which, once formed, remained unchanged during long periods of storage. In the glucose-enriched media, the glucose decreased by about $200 \mathrm{mgm}$. from an initial value of about $600 \mathrm{mgm}$. per $100 \mathrm{ml}$., the change occurring at a more rapid rate and terminating sooner in neutral, than in acid citrate-glucose. The curves of lactic acid accumulation (Figures $7 \mathrm{C}$ and $7 \mathrm{E}$ ) presenting a complementary picture, with the rate and the final levels higher in neutral, than in acid, citrate-glucose solution.

As an over-all index of their metabolic condition, the glycolytic power of erythrocytes was tested by incubating blood samples for 90 minutes at $37^{\circ}$ and measuring the amounts of lactic acid produced and glucose removed during such periods. For the study of the glycolytic faculty of the erythrocytes of citrated blood, which after a few days' storage is depleted of glucose, glucose solution was added before incubation. Inasmuch as no attempt was made to control the $\mathrm{pH}$ closely and since the rate of glycolysis is well known to be dependent upon the $\mathrm{pH}$, being much greater at higher $\mathrm{pH}$ values, the results of the test have only limited quantitative significance. Individual measurements of rates of $10 \mathrm{mgm}$. or less per hour are of doubtful significance and attain importance only when evaluated statistically owing to limitations in the accuracy of the methods used. As shown in Figures $7 \mathrm{~B}, 7 \mathrm{D}$, and $7 \mathrm{~F}$ the glycolytic activity of the erythrocytes ceased earliest in simple citrate and latest in ACD solution. It may also be seen that the erythrocytes had a higher initial glycolysis rate in the 2 neutral media than in the acid one.

The significance of glycolysis in the functioning of erythrocytes lies in the fact that glycolysis is the most important energy-yielding process occurring in the cells. Their oxygen consumption normally is minute, accounting for less than 10 per cent of the energy yielded by glycolysis. The weakness of the aerobic metabolism of erythrocytes is further illustrated by the virtual absence of the Pasteur effect, as indicated by the fact that glycolysis proceeds at essentially the same rate in oxygen as under anaerobic conditions (42). Before accepting the significance of the glycolytic process in the functioning of erythrocytes, one may consider the question of their metabolic energy requirements. These cells, after maturation from the reticulocyte stage, do not appear to undergo further development nor do they multiply. Their most impressive attribute is the biconcave form, which is maintained under a variety of conditions throughout their life. There has been considerable speculation regarding the mechanism for the maintenance of the characteristic form of erythrocytes (43). Generally 2 basic hypotheses have been advanced: (1) the existence of a rigid structure and 

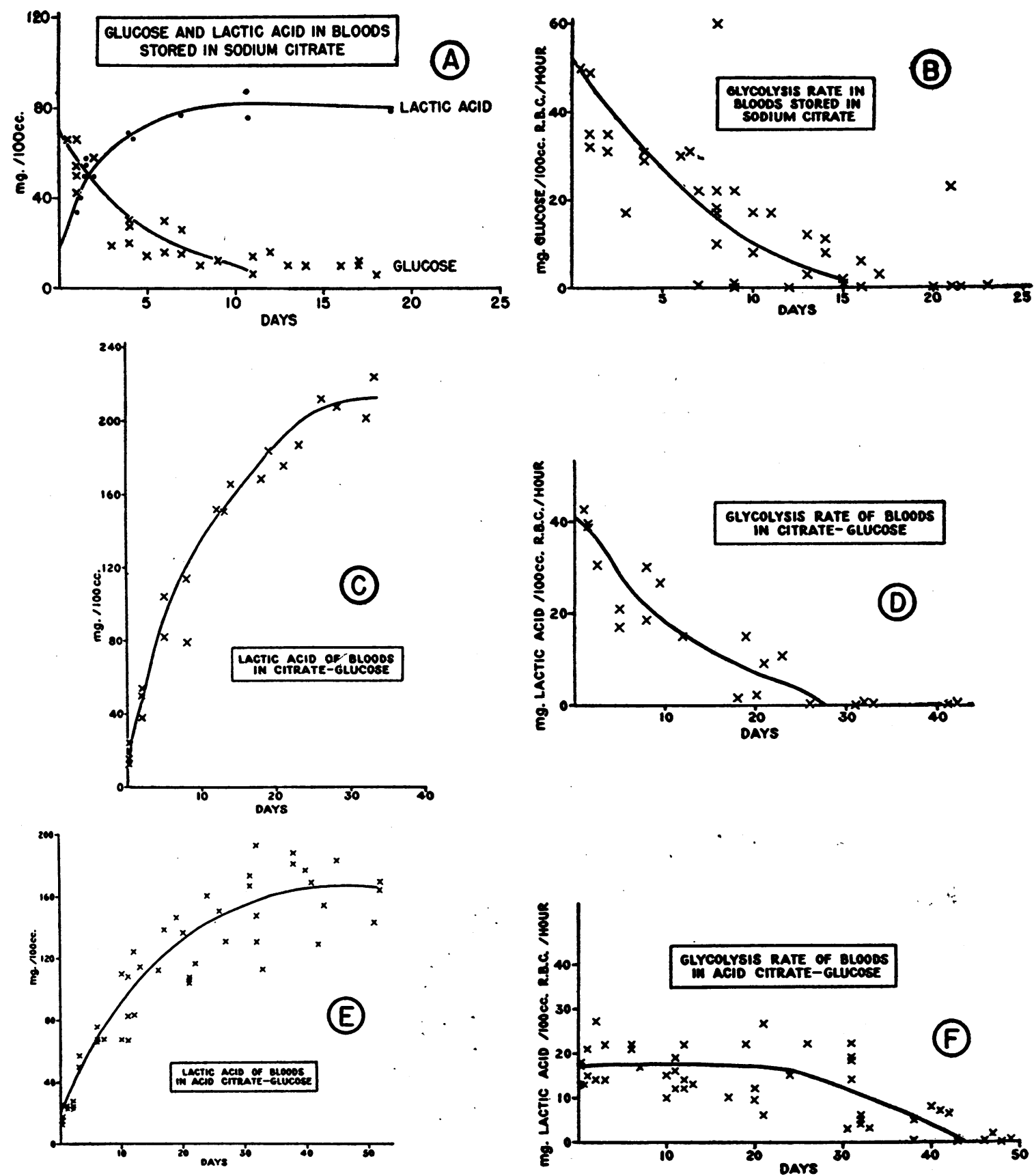

Fig. 7. Changes in Glucose, Lactic Acid and Glycolysis Rate of Bloods Stored in 3 Preservative Solutions

(2) a dynamic balance of forces resulting in constancy of the cellular shape. If, under most conditions, the erythrocytes do not possess a rigid structure, as is indicated by considerable evidence, the conclusion is inescapable that continuous expenditure of energy is required for the preservation of the biconcave form. An attractive hypothesis would then be that in part the function of the glycolytic process is to yield the energy required for the maintenance of the cellular form. ${ }^{3}$ Ac-

${ }^{3}$ Assuming a surface tension of 60 dynes per $\mathrm{cm}$., the energy required by a single cell would be in the order of 

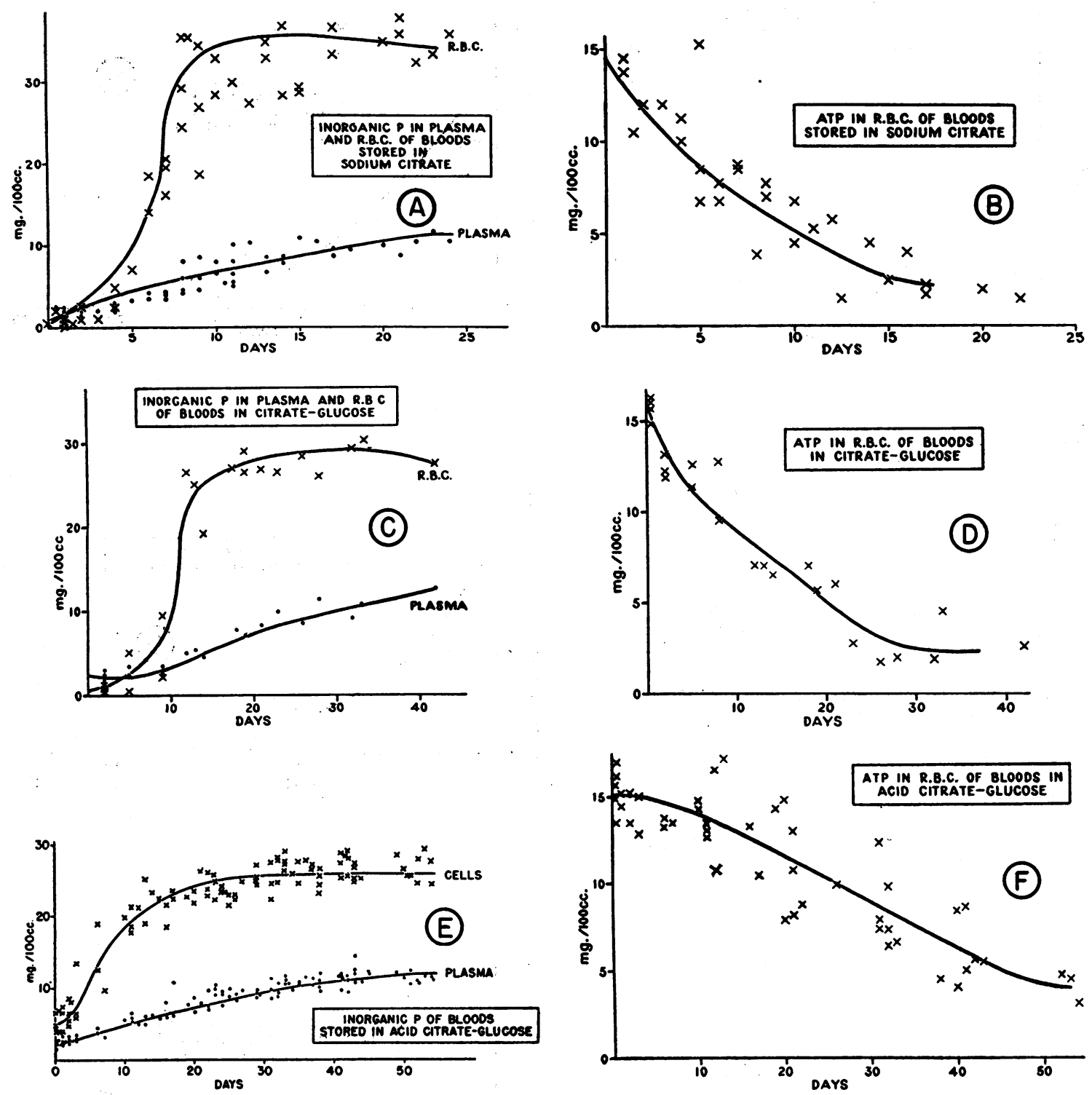

Fig. 8. Changes in the Inorganic Phosphorus Distribution and the Adenosine Triphosphate Content of Red Cells During Storage of Blood in 3 Preservative Solutions

cepting this premise, the similarity of patterns of dimensional and chemical changes and their close correspondence would reflect a causal relationship.

$10^{-6}$ erg. Assuming a corpuscular volume of $90 \mathrm{micra}^{3}$, $100 \mathrm{ml}$. of cells would contain about $10^{12}$ erythrocytes, with an energy requirement of $10^{\circ}$ ergs, that is about $0.25 \mathrm{cal}$. This would correspond to the energy yielded by glycolysis of about $2 \mathrm{mgm}$. of glucose per $100 \mathrm{ml}$. of cells. If the surface tension of the cell and plasma is less, as is indicated by some studies, the energy requirement would be correspondingly decreased.

\section{Acid-soluble phosphorus compounds}

Inorganic phosphorus in cells and plasma: The inorganic phosphorus in the red cells is shown in Figures $8 \mathrm{~A}, 8 \mathrm{C}$, and $8 \mathrm{E}$. In the neutral media, it rose rapidly following a period of delay while in the acid medium, it rose from the start but at a lower rate. The inorganic phosphorus of the plasma in all media rose at an approximately linear rate.

Adenosine triphosphate: The fate of adenosine 
triphosphate (ATP) during storage was of particular interest since this compound is an important co-enzyme of glycolysis. Data for this compound, calculated from the values for the easilyhydrolyzable phosphorus, are presented in Figures $8 \mathrm{~B}, 8 \mathrm{D}$, and $8 \mathrm{~F}$. It may be seen that it decreased most slowly in the blood stored in ACD solution.

Adenosine triphosphate was determined more specifically in several bloods as the easily-hydrolyzable phosphorus in the mercury precipitate of the trichloracetic acid filtrate. The results, not presented here in detail, indicated for citrated blood an initial concentration of about $12 \mathrm{mgm}$. per 100 $\mathrm{ml}$. of cells diminishing to values below $2 \mathrm{mgm}$. after about 10 days of storage. The adenosine triphosphate changes in the glucose-enriched media bore the same relation to those in citrated blood as were given by the cruder method described previously. Studies were also carried out on the fate of the other components of the adenosine triphosphate molecule during storage besides that of the 2 easily hydrolyzable phosphate groups. Adenine, hypoxanthine, and purine nitrogen were determined in the whole blood and in fractions comprising nucleotides on the one hand and nucleosides plus free purines on the other. By following the pentose content of the mercury precipitate of the trichloroacetic acid extract, which contains all the nucleotide and a considerable proportion of the nucleoside, a rough measure of pentose combined with purine was obtained. The results, to be presented in detail elsewhere, indicated that the several parts of the adenosine triphosphate molecule underwent changes during storage according to differing patterns and at varying rates. The most rapid, and for the glycolytic process most critical change, was the loss of the 2 easily hydrolyzable phosphate groups. As a consequence, free adenylic acid accumulated. Adenine was deaminated to hypoxanthine, the conversion reaching as much as 80 per cent. The deamination seemed to be accompanied in each case by the loss of the third phosphate group, leading to the accumulation of hypoxanthine riboside after prolonged periods of storage.

Organic acid-soluble phosphorus: The changes in the organic acid-soluble phosphorus of the cells, which consists for the most part of a mixture of adenosine triphosphate and diphosphoglyceric acid, mirrored to a large extent those of inorganic phos-

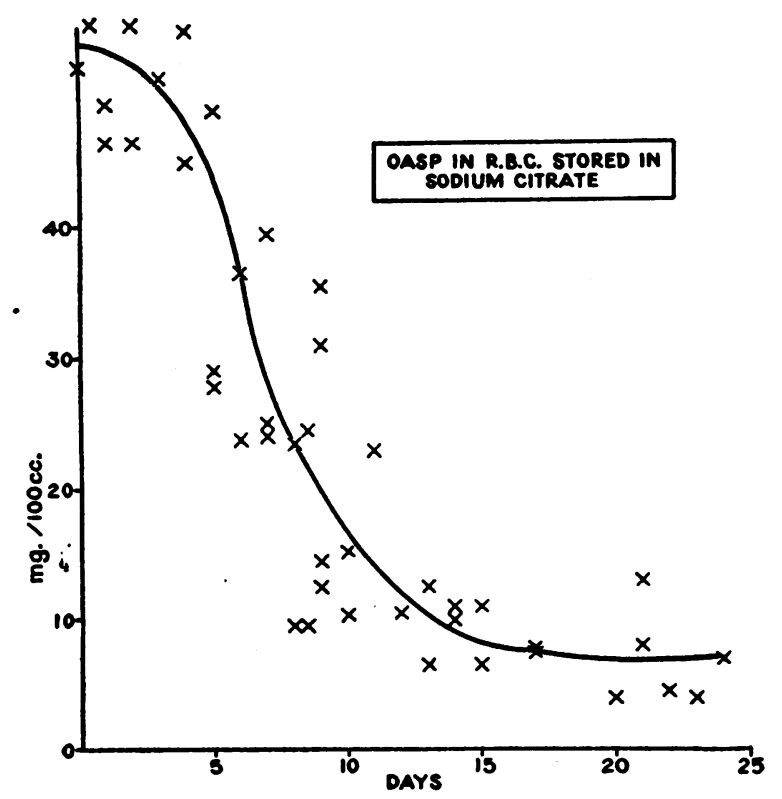

Fig. 9. Organic Acid Soluble Phosphorus in Bloods Stored In Sodium Citrate

phorus as shown for citrated blood in Figure 9.

The total acid-soluble phosphorus content of all bloods remained unchanged even after the most extended storage periods (70 days), indicating that the phospholipids, which in mammalian bloods almost entirely account for the acid-insoluble phosphorus fraction, were not hydrolyzed under such conditions.

A discussion of the changes in the phosphorus distribution of blood during storage necessitates a sketchy review of the changes occurring during glycolysis at $37^{\circ} \mathrm{C}$, and a brief consideration of the role of the phosphorus compounds in the intermediate reactions of the glycolytic process (44). The glycolytic system of the erythrocytes is distinguished by great sensitivity to changes of $\mathrm{pH}$, the over-all rate of glycolysis increasing with elevation of $\mathrm{pH}$. If glycolysis is allowed to proceed at $\mathrm{pH}$ values above 7.3 , the inorganic phosphorus, following a brief period during which the level may decrease, steadily increases, at the expense primarily of adenosine triphosphate and later also of diphosphoglyceric acid. During incubation at $\mathrm{pH}$ values below 7.3, the inorganic phosphorus rises from the start at a rapid rate, while the adenosine triphosphate is maintained at a high level and the diphosphoglyceric acid diminishes swiftly (45). The resemblance beween the changes occurring 
at $37^{\circ} \mathrm{C}$. and those taking place in bloods during storage at low temperatures is obvious: In bloods collected in neutral media, a short period of unchanged or decreased levels of inorganic phosphorus is followed by a breakdown of both adenosine triphosphate and diphosphoglyceric acid, as judged by the data described earlier; in bloods stored in acid citrate-glucose, an immediate rise of the inorganic phosphorus goes hand in hand with the maintenance of high levels of adenosine triphosphate for considerable periods of time. Decreasing values of the total organic acid-soluble phosphorus were, by inference, accounted for by changes in the diphosphoglyceric acid.

In the light of modern concepts of the glycolytic process $(45,46,47)$ the changes in the glycolytic rate and in the distribution of phosphorus compounds at varying $\mathrm{pH}$ values may be interpreted as follows: At elevated $\mathrm{pH}$ values glycolysis proceeds at a rapid rate, while the level of adenosine triphosphate tends to decrease; this indicates that under such circumstances the rate of esterification of glucose by adenosine triphosphate proceeds at a more rapid rate than does the rephosphorylation of adenylic acid. In acidified blood, where the glycolytic rate may be only one-third as great as normal the adenosine triphosphate is maintained at a higher level, indicating that rephosphorylation of adenylic acid keeps pace with the esterification of glucose. This balance is in part ascribable to the decreased over-all rate of turnover ; in addition, under such circumstances diphosphoglyceric acid in decomposing furnishes an additional source of phosphorus for the re-synthesis of adenosine triphosphate. Since adenosine triphosphate appears less susceptible to irreversible deaminating attack than adenylic acid, circumstances leading to minimum concentrations of adenylic acid, such as prevail in acidified blood, tend to slow the rate of breakdown of the essential nucleotides.

From inspection of the data it becomes evident that the glycolytic power of the erythrocytes was still present to some extent at a time when most of the organic acid-soluble phosphorus had decomposed. The lack of correlation between the 2 indices suggests that only a small component of the organic acid-soluble phosphorus, perhaps the adenosine triphosphate, or a portion thereof, constitutes the limiting factor in the glycolytic process.

On the basis of the data presented one may ven- ture the hypothesis that the maintenance of the functional state of the cell and of its various characteristics, dimensional, osmotic, and chemical, is dependent upon the glycolytic process which in turn is dependent on the intact functioning of the enzyme system concerned with it; adenosine triphosphate, or a compound determining its concentration, is of critical importance for the preservation of the glycolytic power of the erythrocytes. It may be surmised that only cells which by virtue of a functioning enzyme structure have the ability to recover their normal physical and chemical structure survive in vivo.

\section{Potassium and sodium}

The changes in the potassium content of serum and cells are portrayed in Figures 10A, 10C, and $10 \mathrm{E}$. It can be seen that the potassium content of plasma of citrated blood increased in the beginning at the rate of about 2.0 meq. per liter per day and more slowly after longer periods, reaching a value halfway towards diffusion equilibrium in about 8 days. Half-diffusion-equilibrium values were reached after 12 days in citrate-glucose and after about 23 days in acid citrate-glucose. The changes of potassium in the cells in each case mirrored faithfully those occurring in plasma.

The sodium in plasma and cells, as shown in Figures 10B, D, and F, underwent in all solutions a change reciprocal to that of the potassium, but at a slower rate. A comparison of the 3 preservatives with regard to sodium leads to essentially the same conclusion as described above for potassium.

It is of interest to examine to what extent the exchange of potassium and sodium between cells and plasma follows the law of simple diffusion, particularly so, in view of the possibility that the normally existing inequality of the ionic concentrations between cells and plasma is maintained by metabolic processes. It would appear that the processes of ionic exchange, except for the first few days, may be described on the assumption of simple diffusion, with rates decreasing in order in citrate, neutral, and acid citrate-glucose solutions.

The changes in the ionic composition of blood during storage have obvious implications with regard to the general theory of permeability of the erythrocyte membrane. On the one hand, it appears that sodium and potassium exchange across the cellular membrane during storage (as indeed 

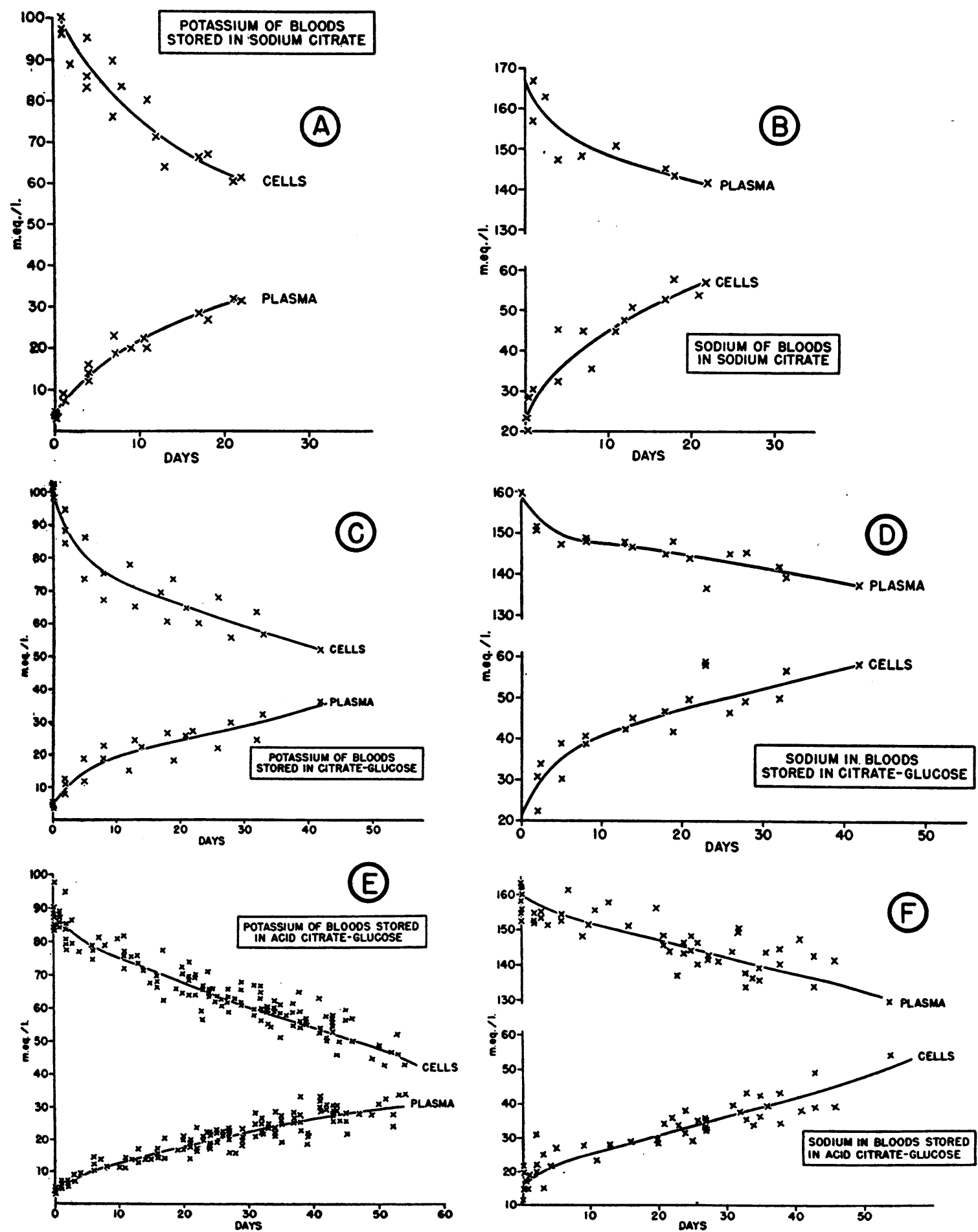

Fig. 10. Changes in Distribution of Potassium and Sodium between Plasma and Cells of Bloods Stored in 3 Preservative Solutions 
in vivo, as shown by the radioactive tracer technique [48 to 50]); on the other hand, there exists considerable evidence which indicates that the exchange of water and anions between cells and plasma may be described by the Donnan theory on the postulate of non-permeability of the erythrocyte membrane to cations $(40,51,52)$. In order to conciliate this apparent contradiction, it has been proposed that the cations exchange across the cellular membrane not by way of simple diffusion, but rather by means of a metabolic process. Such a hypothesis would also account for the unequal distribution of potassium and sodium between cells and plasma. The decrease of cellular potassium during storage may then be thought to be due to unfavorable conditions for the specific metabolic process concerned with the transfer of potassium so that the normally existing steady state is no longer maintained. According to another explanation which is not necessarily in conflict with the one just mentioned, the non-diffusibility of the cations may be due to some form of binding of the cations. However, existing data indicate that at least 90 per cent of the cell water is "free," that is, osmotically active, and that the degree of osmotic activity of cations in the cells does not differ markedly from that in the plasma. It is still conceivable that there exists within the cells a restraining influence which, while preventing the free outward diffusion of cations, interferes little with their osmotic activity. This hypothesis gains interest in line with observations to be presented in the following paragraphs.

In view of the intimate connection between the electrolyte concentration and the water content of the cells, it is of interest to examine the changes during storage in the total concentration of cations. In Table VIII are presented the mean values for the sum of sodium and potassium, taken to represent the total cations, observed on blood in acid citrate-glucose solution initially and after periods of storage of 20 to 40 days. The concentrations in cells and plasma are recorded in meq. per liter of each, and per $\mathrm{kgm}$. of water. On either basis, it it evident that the cells in acid citrate-glucose solution actually lost cations during storage. This loss apparently occurred in a manner that left the water distribution, and with it the cellular volume, unchanged. The amount of cation transferred from cells to plasma agrees well with the value calcu-

\section{TABLE VIII}

Distribution of cations between cells and plasma during storage of blood in acid citrate-glucose solution

The results are expressed as the mean, together with the standard error of the mean.

\begin{tabular}{|c|c|c|c|c|}
\hline $\begin{array}{c}\text { Period } \\
\text { of } \\
\text { storage }\end{array}$ & & $\begin{array}{c}\text { Cells } \\
\mathrm{Na}+\mathrm{K}\end{array}$ & $\begin{array}{l}\text { Plasma } \\
\mathrm{Na}+\mathrm{K}\end{array}$ & $\underset{\text { pH }}{\text { Plasma }}$ \\
\hline $\begin{array}{c}\text { days } \\
0\end{array}$ & $\begin{array}{l}\text { meq. per liter } \\
\text { meq. per kgm. water* } \\
\text { Calculated value** } \\
\text { meq. per liter }\end{array}$ & $\begin{array}{l}108.8 \pm 3.8 \\
148 \\
112\end{array}$ & $\begin{array}{l}160.2 \pm 3.1 \\
168 \\
157\end{array}$ & 6.95 \\
\hline \multirow[t]{2}{*}{$20-30$} & $\begin{array}{l}\text { meq. per liter } \\
\text { meq. per kgm. water* } \\
\text { Calculated value** } \\
\text { meq. per liter }\end{array}$ & $\begin{array}{l}95.3 \pm 1.1 \\
130 \\
100\end{array}$ & $\begin{array}{l}167.7 \pm 1.1 \\
176 \\
164\end{array}$ & 6.50 \\
\hline & $\begin{array}{l}\text { Change during storage: } \\
\text { meq. per liter } \\
\text { meq. per } k g m . \text { water* } \\
p^{* * * *} \\
\text { Calculated value** } \\
\text { meq. per liter }\end{array}$ & $\begin{array}{l}-13.5 \pm 4.0 \\
-18 \\
0.001 \\
-12\end{array}$ & $\begin{array}{l}+7.5 \pm 3.3 \\
+8 \\
<0.05 \\
+7\end{array}$ & -0.35 \\
\hline
\end{tabular}

* A constant value of 0.743 gram per ml. was calculated for the cell water by means of the formula

$$
\mathrm{H}_{2} \mathrm{O}_{c}=94.53-0.704 \mathrm{Hb}_{c}
$$

where $\mathrm{Hb}_{c}$ indicates the concentration of hemoglobin in gram per $100 \mathrm{ml}$. of cells, on the basis of a measured hemoglobin concentration of 30.0 grams per $100 \mathrm{ml}$. The plasma water was assumed to be 0.95 gram per $\mathrm{ml}$.

** These values were calculated by means of equations and assumptions described earlier, on the basic premise that the water distribution between cells and plasma remained constant during storage and that the only variable was the ionic equivalency of hemoglobin, for which the values given by Adair (41) were used. For the calculation of the initial values of cell and plasma water it was assumed that the blood in the beginning was at a $\mathrm{pH}$ close to the iso-ionic point of hemoglobin. As may be seen, the values calculated on this rough approximation were in fairly good agreement with the observed values. Given an acidification to a $\mathrm{pH}$ in the plasma of 6.50 during storage, the changes in the distribution of cations in plasma and cells were calculated with the same values for the serum and cell water as assumed initially.

*** $p=$ the percentage chance that a deviation as great or greater than that observed would arise by chance alone; any value of $p .05$ or less is usually accepted as indicating a significant difference.

lated from the ionic equivalency of hemoglobin when the water content of the cells remains constant. This is also shown in the table. The behavior of the erythrocytes suggests that their corpuscular volume in acidified blood is maintained by a graded transfer of cation in apparent proportionality to the increased ionization of hemoglobin as a cation. To explain the unexpected behavior the following hypothesis may be tentatively adduced: assuming that the apparent non-diffusibility of cations across the cellular membrane is caused by some restricting interaction, perhaps a molecular force existing between the cations and other components within the cell, one may reason 
that the hemoglobin cation competes with the monovalent cations, displacing them from positions previously occupied, perhaps by virtue of its greater size. The displaced monovalent cations, no longer restrained, would then freely leave the erythrocyte. Since diffusible anions would enter the cell in direct proportion to the cationic ionization of hemoglobin and an equal proportion of cations becoming diffusible would leave the cell constant osmolarity and therefore constant water content would be maintained. According to this hypothesis, therefore, erythrocytes would tend to maintain constant volume below the iso-ionic point of hemoglobin, by means of loss of cations in direct proportion to the ionization of hemoglobin as a cation.

\section{STATISTICAL COMPARISON OF 5 INDICES OF BLOOD} PRESERVATION

In Table IX are presented data based on 96 blood samples on the degree of association among the 5 indices of blood stored in 3 preservative solutions. The table contains values for the regression equations and correlation coefficients between percentage hemolysis in 0.6 per cent $\mathrm{NaCl}$ solution, which (as the most precise measurement) was chosen as the basis of comparison on the one hand and the 4 other indices on the other. It may be seen that for each of the preservative solutions close association existed between the alterations of hemolysis in 0.6 per cent $\mathrm{NaCl}$ solution and the changes of any of the 4 other indices, the only exception being glycolysis of blood in simple citrate, the values for which were rather variable. An inspection of the data indicates that the absolute values of the regression coefficients were of similar magnitude in all 3 preservatives. Similarity in the relative rates of change of all 5 indices in the 3 preservatives is indicated by the highly significant values for the regression and correlation coefficients for the pooled values. In Table $\mathrm{X}$ are recorded for the purpose of close comparison the differences among the several regression coefficients for the 3 preservative solutions. It may be seen that except for 2 values, the differences between the several regression coefficients were of small magnitude. When the individual regression coefficients in each of the 3 preservative solutions were compared with the pooled estimate, no statistically significant difference was apparent in any instance.

The similarity of the regression functions with change in hemolysis for the dimensional, metabolic, and chemical characteristics of the red cell in the 3 solutions of widely differing preservative qualities indicates that the several indices displayed similar relationships among each other despite great variations, up to 4-fold, in the rate of change with time. The data as a whole represent indirect evidence of close interdependence of physical, osmotic, and chemical properties of the red cell.

\section{DISCUSSION}

From a review of the composite findings presented, it appears that a number of apparently.unrelated properties of the erythrocyte undergo

TABLE IX

Relationship between hemolysis in 0.6 per cent $\mathrm{NaCl}$ solution and 4 other indices of bloods stored in 3 preservative solutions Regression equations and correlation coefficients

\begin{tabular}{|c|c|c|c|c|c|c|c|c|}
\hline \multirow{2}{*}{ Solution } & \multicolumn{2}{|c|}{ Thickness vs. hemolysis } & \multicolumn{2}{|c|}{$\begin{array}{l}\text { Adenosine triphosphate } \\
\text { vs. hemolysis }\end{array}$} & \multicolumn{2}{|c|}{ Glycolysis vs. hemolysis } & \multicolumn{2}{|c|}{ Potassium vs. hemolysis } \\
\hline & $\begin{array}{l}\text { Regression } \\
\text { equation }\end{array}$ & $\begin{array}{c}\text { Correla- } \\
\text { tion } \\
\text { coefficient }\end{array}$ & $\begin{array}{l}\text { Regression } \\
\text { equation }\end{array}$ & $\begin{array}{c}\text { Correla- } \\
\text { tion } \\
\text { coefficient }\end{array}$ & $\begin{array}{l}\text { Regression } \\
\text { equation }\end{array}$ & $\begin{array}{c}\text { Correla- } \\
\text { tion } \\
\text { coefficient }\end{array}$ & $\begin{array}{l}\text { Regression } \\
\text { equation }\end{array}$ & $\begin{array}{c}\text { Correla- } \\
\text { tion } \\
\text { coefficient }\end{array}$ \\
\hline Citrate & $\begin{array}{c}-0.011+0.0187 x \\
\pm 0.0014\end{array}$ & +0.946 & $\begin{array}{c}10.8-0.123 x \\
\pm 0.017\end{array}$ & -0.866 & $\begin{array}{c}23.7-0.247 x \\
\pm 0.100\end{array}$ & -0.484 & $\begin{array}{c}11.2+0.272 x \\
\quad \pm 0.054\end{array}$ & +0.824 \\
\hline $\begin{array}{l}\text { Citrate- } \\
\text { glucose }\end{array}$ & $\begin{array}{c}0.041+0.0169 x \\
\pm 0.0015\end{array}$ & +0.914 & $\begin{array}{c}11.6-0.145 x \\
\quad \pm 0.017\end{array}$ & -0.914 & $\begin{array}{c}24.3-0.390 x \\
\pm 0.082\end{array}$ & -0.767 & $\begin{array}{c}16.1+0.199 x \\
\quad \pm 0.049\end{array}$ & +0.708 \\
\hline $\begin{array}{l}\text { Acid citrate- } \\
\text { glucose }\end{array}$ & $\begin{array}{c}0.030+0.0145 x \\
\quad \pm 0.0007\end{array}$ & +0.960 & $\begin{array}{c}13.2-0.142 x \\
\pm 0.017\end{array}$ & -0.767 & $\begin{array}{c}17.5-0.283 x \\
\pm 0.039\end{array}$ & -0.753 & $\begin{array}{c}9.7+0.345 x \\
\quad \pm 0.028\end{array}$ & +0.870 \\
\hline $\begin{array}{l}\text { Pooled value } \\
\text { of } 3 \text { preser- } \\
\text { vatives }\end{array}$ & $\begin{aligned} 0.014 & +0.0168 x \\
& \pm 0.0006\end{aligned}$ & +0.922 & $\begin{array}{c}12.6-0.147 x \\
\pm 0.004\end{array}$ & -0.755 & $\begin{array}{c}20.1-0.281 x \\
\pm 0.042\end{array}$ & -0.539 & $\begin{array}{c}11.5+0.285 x \\
\quad \pm 0.023\end{array}$ & +0.732 \\
\hline
\end{tabular}




\section{TABLE $X$}

Relationship between hemolysis in 0.6 per cent $-\mathrm{NaCl}$ solution and 4 other indices of bloods stored in 3 preservative solutions

Differences between regression coefficients and estimates of their significance

\begin{tabular}{|c|c|c|c|c|}
\hline Comparison & $\begin{array}{l}\text { Thickness } \\
\text { vs. } \\
\text { hemolysis }\end{array}$ & $\begin{array}{c}\text { Adenosine } \\
\text { triphos- } \\
\text { phate } \\
\text { vs. } \\
\text { hemolysis }\end{array}$ & $\begin{array}{c}\text { Gly- } \\
\text { colysis } \\
\text { vs. } \\
\text { hemoly- } \\
\text { sis }\end{array}$ & $\begin{array}{l}\text { Potas- } \\
\text { sium } \\
\text { v8. } \\
\text { hemoly- } \\
\text { sis }\end{array}$ \\
\hline $\begin{array}{l}\text { Citrate vs. citrate- } \\
\text { glucose } \\
\text { p }^{*}\end{array}$ & $\begin{array}{c}+0.0018 \\
\pm 0.0020 \\
0.4\end{array}$ & $\begin{array}{c}+0.022 \\
\pm 0.024 \\
0.4\end{array}$ & $\begin{array}{c}+0.143 \\
\pm 0.133 \\
0.3\end{array}$ & $\begin{array}{l}+0.073 \\
\pm 0.073 \\
0.3\end{array}$ \\
\hline $\begin{array}{l}\text { Citrate vs. acid } \\
\text { citrate-glucose } \\
\text { p }^{*}\end{array}$ & $\begin{array}{c}+0.0042 \\
\pm 0.0015 \\
0.01\end{array}$ & $\begin{array}{c}+0.003 \\
\pm 0.024 \\
0.9\end{array}$ & $\begin{array}{c}-0.036 \\
\pm 0.112 \\
0.8\end{array}$ & $\begin{array}{c}-0.073 \\
\pm 0.061 \\
0.3\end{array}$ \\
\hline $\begin{array}{l}\text { Citrate-glucose vs. } \\
\text { acid citrate- } \\
\text { glucose } \\
\text { p }^{*}\end{array}$ & $\begin{array}{c}+0.0024 \\
\pm 0.0016 \\
0.15\end{array}$ & $\begin{array}{c}-0.019 \\
\pm 0.024 \\
0.5\end{array}$ & $\begin{array}{c}+0.107 \\
\pm 0.091 \\
0.3\end{array}$ & $\begin{array}{c}-0.146 \\
\pm 0.057 \\
0.02\end{array}$ \\
\hline
\end{tabular}

* $p=$ percentage chance that a deviation as great or greater than that observed would arise by chance alone; any value of $p \mathbf{0 . 0 5}$ or less is usually accepted as indicating a significant difference. The bold-faced figures indicate significant differences.

changes in a characteristic manner during storage. These alterations follow a similar pattern in each of the 3 preservatives studied. A brief listing of the cellular characteristics which changed in a critical and characteristic manner during storage may be useful at this point. They were: (1) hemolysis in several concentrations of $\mathrm{NaCl}$ solution from 0.9 per cent down, (2) dimensional changes of the er. throcyte, i.e., in diameter, thickness, and surface area, (3) glycolyzing power, (4) adenosine triphosphate content, and (5) change in the distribution of potassium. Not all physical or chemical properties of the cell followed this pattern; for instance, the corpuscular volume appears to be determined by the osmotic and ionic relationships existing between cells and serum rather than by the functional state of the cell. The liberation of inorganic phosphorus and alterations of the glutathione content belong also in the group of cellular properties, which did not change in a manner which can be correlated with the preservation of the red cell. Such differences in behavior suggest that, while some of the cellular properties are intimately related to the metabolic activity of the cell and reflect its functional state, others do not bear such a relationship. To some extent, the division may be artificial and dependent on the scale and method of measurement adopted. This is illustrated by the conflicting experiences with the use of osmotic hemolysis as an index of blood preservation.

\section{Comparison of in vitro and in vivo tests}

The practical importance of in vitro data hinges on their close correlation to the in vivo survival of erythrocytes. In order to compare the results reported here with the in vivo behavior of stored blood, the data on the percentage survival of erythrocytes 7 days after transfusion obtained (6) by a differential agglutination method have been charted in Figure 11. The preservatives tested by

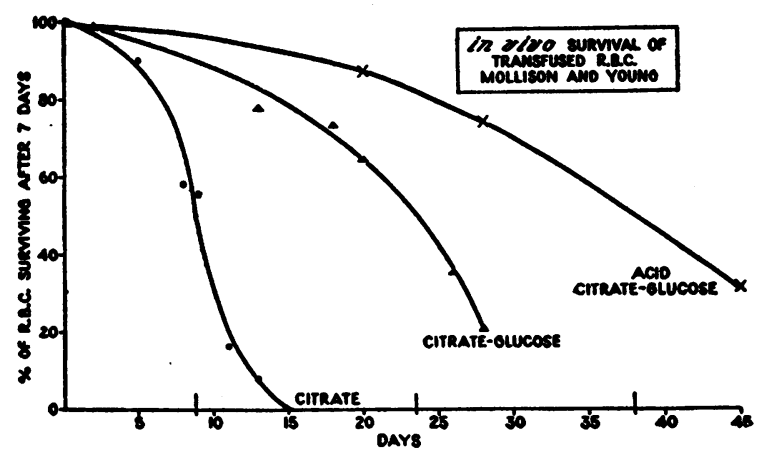

Fig. 11. In vivo Survival of Erythrocytes of Bloods Stored in 3 Preservative Solutions According to Data of Mollison and Young (6)

the British workers, except for the use of a higher concentration of citrate in the neutral media, were closely comparable to those studied here. Similar results have been obtained by the use of radioactive iron for the direct measurement of the survival of the erythrocytes (Gibson, Ross). The close correspondence between in vitro and in vivo results indicates the practical usefulness of in vitro methods and supports the initial hypothesis of close interrelation between many properties of the red cell.

The principal applications of in vitro methods appear to be two: first, as preliminary procedures for the screening of preservative solutions before they are submitted to definitive testing by established in vivo methods. Their rapidity, sensitivity and accuracy, make them well suited for this purpose. As to accuracy, one advantage lies in the fact that only the variability of the donor comes into play, whereas in vivo testing is affected by the cumulative variabilities of donor and recipient. 
Second, in vitro methods have their widest field of use in the investigation of the mechanism of deteriorative processes of the cell and constitute therefore the basis for rational elaboration of improved preservative techniques. For instance, they already appear to furnish some understanding of the apparent advantage of the addition of glucose and of acid to blood. Their failure under certain conditions to reflect the functional state of the cell is perhaps more an index of the deficiencies of our understanding than a general argument against their validity. The employment of a series of indices for the description of the preservation of the red cell should help to guard against the danger of reliance on any single index, which under certain experimental conditions may prove to be a fallacious guide.

\section{Practical considerations}

While the length of preservation appears of paramount importance in the selection of preservative solutions, other factors merit attention in the consideration of the practical usefulness of any preservative. Among these may be mentioned: (1) ease of sterilization of the preservative solution, (2) extent of dilution of the blood, (3) suitability for the subsequent preparation of fluid or dried plasma, and (4) possible deleterious effects of ingredients of the preservative solutions proposed. For instance, with respect to the first point, neutral citrate-glucose solution, which requires a special technique to prevent caramelization of glucose, is at a disadvantage compared with simple citrate solution. ACD solution on the other hand may be sterilized as simply as citrate solution alone. In view of the superiority of this solution with respect to the longevity of red cells, the subsequent discussion will be limited to consideration of its merits and demerits. Its use entails a dilution of blood to the extent of 25 per cent, so that the concentration of protein in the plasma is reduced to about 5.1 grams per $100 \mathrm{ml}$., assuming an initial concentration of 7 grams per $100 \mathrm{ml}$. and taking into account the swelling of the erythrocytes. The protein concentration of plasma of blood in simple citrate, calculated on the same assumption, is about 5.8 grams per $100 \mathrm{ml}$. With respect to the preparation of dried plasma, some increase in drying time may be expected owing to the presence of glucose in acid citrate-glucose solution. The possibility of deleterious effects of the acidification of blood may be dismissed on theoretical grounds as well as on the basis of practical experience. Injection of an organic acid, which is easily metabolized in the body with the production of $\mathrm{CO}_{2}$, in amounts such as are added to blood, may be confidently expected not to produce an appreciable effect on the ionic equilibrium of the blood of the recipient. Direct experiments on this point have been carried out (6). A comparable condition exists in any stored blood, where the amounts of lactic acid accumulated are about as much as the amounts of citric acid added. In summary one may therefore say that, while acid citrate-glucose solution produces a somewhat more dilute plasma and may give rise to minor difficulties in the production of dried plasma, its greatly superior preservative qualities make it the preservative solution of choice.

\section{SUMMARY}

On the basic premise that the erythrocyte represents a functional unit, with closely interdependent physical and chemical properties, which in turn are related to its viability, a study of dimensional, osmotic, and chemical changes of blood stored in 3 preservative solutions was undertaken. The preservatives studied were: (1) simple citrate solution, (2) a neutral, and (3) an acid citrateglucose (ACD) solution. The results of this investigation may be summarized as follows:

(1) During storage red cells undergo a change in their dimensions in a characteristic and critical manner; their thickness increases, their diameter decreases, and their apparent surface area is reduced. These alterations are interpreted as manifestations of progressive deterioration of the cell. They progress most rapidly in blood in simple citrate, and most slowly in blood in acid citrateglucose solution. Changes in the corpuscular volume appear to be determined by physico-chemical relationships and not to be related to the functional state of the cell.

(2) Osmotic hemolysis of erythrocytes becomes similarly altered in a progressive manner during storage, at a rapid rate in simple citrate and most slowly in acid citrate-glucose solution.

(3) The plasma $\mathrm{pH}$ decreases to a value of 7.1 
in simple citrate solution, and to a value below 6.6 in the glucose-enriched media in direct relation to the amount of lactic acid accumulated.

(4) The ability of the red cells to glycolyze is lost first in simple citrate solution and is preserved longest in acid citrate-glucose solution.

(5) The inorganic phosphorus increases sharply in the red cells, with corresponding decrease of the organic acid-soluble phosphorus, but changes in a more gradual manner in the plasma. Adenosine triphosphate, a co-enzyme of blood glycolysis, is preserved considerably longer in blood in ACD solution than in the 2 neutral media. Maintenance of adenosine triphosphate appears of importance for the preservation of the metabolic function of erythrocytes.

(6) Decreases of potassium and increases of sodium in erythrocytes reported by others have been confirmed. During storage the total cation content of erythrocytes detreases. This fact and the constancy of the corpuscular volume of erythrocytes in ACD solution during storage are interpreted as indicating loss of cations on the acid side of the iso-ionic point of hemoglobin, in direct proportion to the dissociation of hemoglobin as a cation, with the osmolarity of the cells remaining constant.

Judged by various indices the state of erythrocytes of citrated blood after 8 days is approximately equivalent to their state in neutral citrateglucose after 18 days, and in ACD solution after 33 days.

It would appear that in vitro testing has its place in the study of preservation of erythrocytes (1) as a useful preliminary procedure for the screening of preservative solutions before these submitted to definitive testing by direct measurement of their survival in vivo, and (2) as a useful tool in the development of improved methods of blood preservation on a rational basis.

ACD solution is recommended for practical use.

\section{ACKNOWLEDGMENT}

I should like to thank primarily Dr. G. M. Guest for his interest and encouragement; discussion with him provided the initial stimulus for this investigation. I am greatly indebted to Dr. P. Hoxworth, Director of the Blood Bank of the Cincinnati General Hospital, for his help in obtaining blood samples and generously providing the facilities of the blood bank, and to Mrs. E. W. Brown for her advice in the statistical planning and her aid in the statistical analysis of the data. I am grateful to Mrs. M. G. Moore, Mrs. B. Hobson, Mrs. M. S. Mellette, and Miss E. Foy for technical assistance and to Mrs. D. Vergon and Miss A. Hobson for help in the preparation of the manuscript.

\section{BIBLIOGRAPHY}

1. Rous, P., and Turner, J. R., The preservation of living red blood cells in vitro. I. Methods of preservation. II. The transfusion of kept cells. J. Exper. Med., 1916, 23, 219.

2. Maizels, M., and Whittaker, N., Effects of storage on human erythrocytes. Lancet, 1940, 1, 113.

3. Wilbrandt, W., Ueber Konservierung menschlichen Blutes. Schweiz. Med. Wchnschr., 1940, 70, 731.

4. Mollison, P. L., and Young, I. M., In vivo survival in the human subject of transfused erythrocytes after storage in various preservative solutions. Quart. J. Exper. Physiol., 1942, 31, 359.

5. Bushby, S. R. M., Kekwick, A., Marriott, H. L., and Whitby, L. E. H., Survival of stored red cells after transfusion. Lancet, 1940, 2, 414.

6. Loutit, J. F., Mollison, P. L., and Young, I. M., Citric acid-sodium citrate-glucose mixtures for blood storage. Quart. J. Exper. Physiol., 1943, 32, 183.

7. De Gowin, E. L., Harris, J. E., and Plass, E. D., Studies on preserved human blood. I. Various factors influencing hemolysis. J. A. M. A., 1940, 114, 850.

8. Alsever, J. B., and Ainslie, R. B., A new method for the preparation of diluted blood plasma and the operation of a complete transfusion service. New York State J. Med., 1941, 41, 126.

9. Muether, R. O., and Andrews, K. R., Studies on stored blood. II. Effect of storage on human blood. Am. J. Clin. Path., 1941, 11, 314.

10. Mollison, P. L., and Young, I. M., Failure of in vitro tests as a guide to the value of stored blood. Brit. M. J., 1941, 2, 797.

11. Maizels, M., Phosphate, base and hemolysis in stored blood. Quart. J. Exper. Physiol., 1943, 32, 143.

12. Belk, W. P., Henry, N. W., and Rosenstein, F., Observations on human blood stored at 4 to 6 degrees centigrade. Am. J. M. Sc., 1939, 198, 631.

13. Belk, W. P., and Rosenstein, F., Effect of glucose in preservation of citrated human blood stored at $4^{\circ}$ to $6^{\circ}$ centigrade. Am. J. M. Sc., 1941, 201, 841.

14. Strumia, M. M., Symposium on new trends in surgery. The fate of transfused refrigerated blood and the problem of blood banks. S. Clin. North America, 1942, 22, 1693.

15. Bagdassarov, A., Le problème de la transfusion du sang conservé. Sang, 1937, 11, 466.

16. Dubash, J., Clegg, O., and Vaughan, J., Changes occurring in blood stored in different preservatives. Brit. M. J., 1940, 2, 482.

17. De Gowin, E. L., Harris, J. E., Bell, J., and Hardin, 
R. C., Osmotic changes in erythrocytes of human blood during storage. Proc. Soc. Exper. Biol. and Med., 1942, 49, 484.

18. Crosbie, A., and Scarborough, H., Studies on stored blood. Further observations on the effect of storage on erythrocytes. Edinburgh M. J., 1942, 49, 40.

19. Drew, C. R., Edsall, K., and Scudder, J., Studies in blood preservation. Fate of cellular elements in relation to potassium diffusion. J. Lab: and Clin. Med., 1939, 25, 240.

20. De Gowin, E. L., Harris, J. E., and Plass, E. D., Changes in human blood preserved for transfusion. Proc. Soc. Exper. Biol. and Med., 1939, 40, 126.

21. Conway, E. J., Apparatus for micro-determination of certain volatile substances. IV. The blood ammonia, with observations on normal human blood. Biochem. J., 1935, 29, 2755.

22. Conway, E. J., and Cooke, R., Blood ammonia. Biochem. J., 1939, 33, 457.

23. Smith, M. E., Tuthill, E., Drew, C. R., and Scudder, J., Studies in blood preservation. Some effects of carbon dioxide. J. Biol. Chem., 1940, 133, 499.

24. Dulière, W. L., La teneur en potassium et l'age d'un sérum. Compt. rend. Soc. de biol., 1931, 107, 261.

25. Jeanneney, G., and Servantie, L., Valeur du dosage de potassium comme test d'alteration du sang conservé. Compt. rend. Soc. de biol., 1938, 129, 1189.

26. De Gowin, L. E., Harris, J. E., and Plass, E. D., Studies on preserved human blood. II. Diffusion of potassuim from the erythrocytes during storage. J. A. M. A., 1940, 114, 855.

27. Downman, C. B. B., Oliver, J. O., and Young, I. M., Partition of potassium in stored blood. Brit. M. J., 1940, 1, 559.

28. Maizels, M., and Paterson, J. H., Survival of stored blood after transfusion. Lancet, 1940, 2, 417.

29. Aylward, F. X., Mainwaring, B. R. S., and Wilkinson, J. F., Effects of some preservatives on stored blood. Lancet, 1940, 1, 685.

30. Maizels, M., Preservation of organic phosphorus compounds in stored blood by glucose. Lancet, 1941, $1,722$.

31. Denstedt, O. F., Osborne, D. E., Roche, M. N., and Stansfield, H., Problems in the preservation of blood. Canad. M. A. J., 1941, 44, 448.

32. Loutit, J. F., and Mollison, P. L., Advantages of a disodium-citrate-glucose mixture as a preservative. Brit. M. J., 1943, 2, 744.

33. Maizels, M., Observations on stored blood. Report to M.R.C. Blood Transfusion Research Committee, January, 1943.

34. Guest, G. M., and Wing, M., Osmometric behavior of normal human erythrocytes. J. Clin. Invest., 1942, 21, 257.

35. Rapoport, S., and Guest, G. M., The effect of salicylates on the electrolyte structure of the blood plasma. I. Respiratory alkalosis in monkeys and dogs after sodium and methyl salicylate; the influence of hypnotic drugs and of sodium bicarbonate on salicylate poisoning. J. Clin. Invest., 1945, 24, 759.

36. Nelson, N., A photometric adaptation of the Somogyi method for the determination of glucose. J. Biol. Chem., 1944, 153, 375.

37. Friedemann, T. E., Cotonio, M., and Shaffer, P. A., The determination of lactic acid. J. Biol. Chem., 1927, 73, 335.

38. Dacie, J. V., and Vaughan, J. M., Fragility of red blood cells; its measurement and significance. J. Path. and Bact., 1938, 46, 341.

39. Jacobs, M. H., and Parpart, A. K., Osmotic properties of the erythrocyte. II. The influence of $\mathrm{pH}$, temperature, and oxygen tension on hemolysis by hypotonic solutions. Biol. Bull., 1931, 60, 95.

40. Van Slyke, D. D., Wu, H., and McLean, F. C., Studies of gas and electrolyte equilibria in the blood. V. Factors controlling the electrolyte and water distribution in the blood. J. Biol. Chem., 1923, 56, 765.

41. Adair, G. S., Hemoglobin šystem. Relation of hemoglobin and bases. J. Biol. Chem., 1925, 63, 517.

42. Lundsgaard, E., Die Glykolyse. Ergeb. d. Enzymforsch., 1933, 2, 179

43. Ponder, E., The Mammalian Red Cell and the Propperties of Haemolytic Systems. Berlin, Gebr. Borntraeger, 1934.

44. Guest, G. M., and Rapoport, S., Organic acid-soluble phosphorus compounds of the blood. Physiol. Rev., 1941, 21, 410.

45. Rapoport, S., and Guest, G. M., Decomposition of diphosphoglycerate in acidified blood: its relationship to reactions of the glycolytic cycle. J. Biol. Chem., 1939, 129, 781.

46. Hevesy, G., and Aten, A. H. W., Interaction of plasma phosphate with the phosphorus compounds present in the corpuscles. Kgl. Danske Videnskab. Sleskab. Biol. Medd., 1939, 14, no. 5.

47. Hevesy, G., and Hahn, L., Rate of renewal of the acid-soluble organic phosphorus compounds in the organs and the blood of the rabbit. $\mathrm{Kgl}$. Danske Videnskab. Sleskab. Biol. Medd., 1940, 15, no. 7.

48. Dean, R. B., Noonan, T. R., Haege, L., and Fenn, W. O., Permeability of erythrocytes to radioactive potassium. J. Gen. Physiol., 1941, 24, 353.

49. Hahn, L., Hevesy, G., and Rebbe, O. H., Do the potassium ions inside the muscle cells and blood corpuscles exchange with those present in the plasma? Biochem. J., 1939, 33, 1549.

50. Cohn, W. E., and Cohn, E. T., Permeability of red corpuscles of the dog to sodium ion. Proc. Soc. Exper. Biol. and Med., 1939, 41, 445.

51. Rapoport, S., and Guest, G. M., Role of diphosphoglyceric acid in the electrolyte equilibrium of blood cells: studies of pyloric obstruction in dogs. J. Biol. Chem., 1939, 131, 675.

52. Rapoport, S., Stevens, C. D., Engel, G. L., Ferris, E. B., and Logan, M., The effect of voluntary overbreathing on the electrolyte equilibrium of arterial blood in man. J. Biol. Chem., 1946, 163, 411. 